\title{
COMMENTS
}

\section{THE ROLE OF FEDERAL COURTS IN CHANGING STATE LAW: THE EMPLOYMENT AT WILL DOGTRINE IN PENNSYLVANIA}

\author{
MARK R. KRAMER $\dagger$
}

When state law is unclear or rapidly changing, federal courts in diversity jurisdiction face an awkward predicament. The doctrine of Erie Railroad $v$. Tompkins ${ }^{1}$ requires that they anticipate the law as state courts would decide it. Federal courts, however, are often reluctant to acknowledge indications of change in state law and tend to avoid critical reappraisal of older state precedents. ${ }^{2}$ This Comment examines the justifications for that reluctance and suggests that such constricted adjudication does not further the policies of federalism. Excessive restraint may even distort the development of state law.

Part I briefly reviews the Erie doctrine and its implications for federal courts anticipating state law, concluding that the policies of Erie and its recent progeny, though developed in the context of procedural law, must inform the process of determining state substantive law. Part II offers jurisprudential arguments that critical reappraisal and independent analysis are essential elements of adjudication. Part III traces the interplay of state and federal courts in a specific context: the emer-

† B.A. 1979, Brandeis University; M.B.A. 1982, J.D. Candidate, 1985, University of Pennsylvania. The author wrote this Comment while a student at the University of Pennsylvania Law School.

1304 U.S. 64 (1938).

2 Federal judges repeatedly profess a desire to avoid initiating change in state law. As Judge Wyzanski observes,

The impression that I gather from the cases is that a federal judge sitting in a diversity jurisdiction case is less willing to depart from obsolete doctrines than when he sits in a purely federal case. And this reluctance is not apt to be modified by the action of his superiors in the federal courts . . . . Thus the total tendency of the Erie Railroad doctrine has a strong reactionary direction which it is hard to believe its proponents and expansionists appreciated.

Wyzanski, A Trial Judge's Freedom and Responsibility, 65 HARv. L. REv. 1281, 1300-01 (1952). See also, e.g., Boniuk v. New York Medical College, 535 F. Supp. 1353, 1356-58 (S.D.N.Y.) (recognizing lower state court and nationwide trends of change but refusing to initiate modifications in the employment at will doctrine), affd mem., 714 F.2d 111 (2d Cir. 1982). 
gence of exceptions to the employment at will doctrine in Pennsylvania. ${ }^{3}$

The Pennsylvania Supreme Court has addressed the question of exceptions to the employment at will doctrine only once, a decade ago. ${ }^{4}$ Since then, the handful of Pennsylvania superior courts that have reached the exceptions have aggressively expanded them in nearly every case. ${ }^{5}$ Seeking to avoid intrusion into state law, however, federal courts interpreted the exceptions narrowly from the first. Lacking further guidance from the Pennsylvania Supreme Court, ${ }^{6}$ federal courts became increasingly enmeshed in precedents of federal creation and came to

3 The employment at will doctrine has long permitted an employer to discharge an employee arbitrarily, unless the discharge is contrary to an explicit contractual obligation. See infra notes 79-82 and accompanying text. This doctrine covers most of the workforce. See Note, Reforming At-Will Employment Law: A Model Statute, $16 \mathrm{U}$. MICH. J.L. REF. 389, 389 \& n.1 (1983). Courts have applied the doctrine harshly, upholding terminations without cause and for malicious and illegal causes. See, e.g., Hinrichs v. Tranquilaire Hosp., 352 So. 2d 1130 (Ala. 1977) (discharge for refusal to falsify medial records); Mallard v. Boring, 182 Cal. App. 2d 390, 6 Cal. Rptr. 171 (1960) (upholding discharge for jury duty); Payne v. Western \& Atl. R.R., 81 Tenn. 507, 518-19 (1884) (approving terminations for "good cause or for no cause, or even for bad cause"), overruled on other grounds sub nom. Hutton v. Watters, 132 Tenn. $527,544,179$ S.W. 134, 138 (1915). In the past decade a majority of states have diluted the doctrine with judicially created exceptions. See infra notes 89-106 and accompanying text.

4 See Geary v. United States Steel Corp., 456 Pa. 171, 319 A.2d 174 (1974), discussed infra text accompanying notes 107-25.

S See infra notes 126-41 and accompanying text. The most notable exception is Richardson v. Charles Cole Memorial Hosp., 466 A.2d 1084 (Pa. Super. 1983), a case of first impression in Pennsylvania, involving wrongful discharge based on a violation of the terms of an employment manual. The court relied on only federal precedent in its search for Pennsylvania law, which may account for Richardson's anomalous result. Even Richardson, however, acknowledged that Geary v. United States Steel Corp., 456 Pa. 171, 319 A.2d 174 (1974), created a cause of action for discharge contrary to public policy. Richardson has been squarely contradicted by a more recent Pennsylvania superior court case. See Banas v. Matthews Int'l Corp., No. 1205 (Pa. Super. June 15, 1984).

6 The Internal Operating Procedures of the Third Circuit do not allow one panel to reverse a prior panel's interpretation of state law unless an intervening state supreme court decision has clearly announced the change. See Wolk v. Saks Fifth Avenue, Inc., 728 F.2d 221, 224 n.3 (3d Cir. 1984) (citing Third Gir. Internal Operating P. VIII(C) ("[N]o subsequent panel overrules a published opinion of a previous panel."), reprinted in 28 U.S.C.A. 78 (West Supp. 1984)); see also Telephone Conversation with Judge Adams's Chambers (June 1, 1984) (interpreting Internal Operating Procedure to forbid any panel to revise Third Circuit's interpretation of state law absent an intervening decision from state's highest court). Because district courts are bound by Third Circuit decisions, no change in state law may be recognized by federal courts within the Third Circuit unless it is first announced by the state's supreme court. This Internal Operating Procedure seems directly to contradict West v. American Tel. \& Tel. Co., 311 U.S. 223 (1940), which directs federal courts to ascertain state law from all available data, including the holdings of intermediate state courts. In more practical terms, the Third Circuit rule and others like it leave federal courts bound by precedent from a time when the trend in state law was less apparent. 
diverge noticeably from the more aggressive holdings of the intermediate state courts. Only last year, in Novosel $v$. Nationwide Insurance Co., ${ }^{7}$ did Judge Adams of the Third Circuit finally offer a more expansive reading of current state law that took into account the decisions of intermediate Pennsylvania courts. Although crafted to avoid an explicit overruling, the Novosel decision contradicted prior Third Circuit interpretations. ${ }^{8}$ Strong criticism followed on Erie grounds, ${ }^{8}$ and earlier this year Judge Adams retreated to a position more in line with Third Gircuit precedent than with emerging state law. ${ }^{10}$

Part IV of this Comment examines the current posture of state and federal courts regarding Pennsylvania's employment at will doctrine, arguing that Novosel has come closest to reflecting current state law and furthering the principles of Erie. The Comment concludes with a brief assessment of the substantive merits of the federal variant of the Pennsylvania doctrine, concluding that, quite apart from the Erie issue, it rests on shaky analytic foundations.

\section{ReQuirements of the ERIE Doctrine}

The doctrine of Erie Railroad $v$. Tompkins ${ }^{11}$ requires that federal courts sitting in diversity jurisdiction apply state substantive law, decisional as well as statutory and constitutional. ${ }^{12}$ Most cases in which the Supreme Gourt has explicated this doctrine have focused on the elusive distinction between substantive law and procedural law ${ }^{13}$ - for federal courts, even in diversity, apply federal rules of procedure. In some cases, however, the substance/procedure inquiry is only the first step in

7721 F.2d 894 (3rd Cir. 1983) (recognizing a cause of action for discharge against public policy where employee was fired for refusing to participate in employer's lobbying campaign).

- In particular, Novosel presented a version of Pennsylvania law directly contrary to Bruffett v. Warner Communications, Inc., 692 F.2d 910 (3d Cir. 1982). Novosel presented a distinguishable fact pattern and did not overrule Bruffett. Nevertheless, one of the two rationales for the Bruffett holding was that Pennsylvania would not yet recognize a common law action for wrongful discharge in violation of public policy. Novosel held that Pennsylvania would recognize such an action. No state cases reached the issue between these two decisions. For further discussion of the tension between these two cases, see infra notes 155-85 and accompanying text.

- See, e.g., Novosel, 721 F.2d at 903 (Becker, J., dissenting from denial of petition for rehearing en banc). Judge Becker stated that Novosel virtually overruled the Pennsylvania Supreme Court. He also asserted, citing one of the few Pennsylvania state cases to deny a wrongful discharge action, that "Pennsylvania itself has apparently shown no inclination to undertake" the path chosen in Novosel. Id.

10 See Wolk v. Saks Fifth Avenue, Inc., 728 F.2d 221 (3d Cir. 1984) (affirming dismissal of complaint of wrongful discharge for refusing supervisor's sexual advances).

11304 U.S. 64 (1938).

12 See id. at 78.

1s See, e.g., Hanna v. Plumer, 380 U.S. 460, 471, 472 (1965). 
identifying the applicable legal rule, for a federal court may confront substantive issues on which the law of the forum state is unsettled.

This section first sets forth the underlying purposes of the Erie rule by reviewing the reasoning of decisions dealing with the substance/procedure distinction. It then argues that these same purposes should guide federal courts in interpreting state law. Specifically, federal courts betray the spirit of Erie when they refuse to reconsider an outdated precedent of the state's highest court. If a lower state court would deviate from that precedent, a federal court that adheres to it is not providing the same adjudication as a state court.

\section{A. Policies Informing the Choice of State Substantive Law}

Prior to Erie, federal courts applied state statutory law but decided common law questions with complete independence. ${ }^{14}$ This led to significant variation between federal and state courts in the interpretation of statutes and in the results of litigation. ${ }^{15}$ Skillful forum selection enabled out-of-state litigants to gain substantial tactical advantages. ${ }^{16}$ Substantive rights within the state varied according to the court of their enforcement, subjecting citizens to different and contradictory interpretations and threatening the equitable application of the laws. ${ }^{17}$ State autonomy was threatened insofar as federal courts could enforce rules of substantive law within a state that differed from those enunciated by the state's own courts. ${ }^{18}$ To remedy this situation, the Erie Court held that state substantive law must be applied, whether of statutory or judicial origin. ${ }^{18}$ Its goal was to produce uniformity between the decisions of state and federal courts. ${ }^{20}$

The Erie decision, however, did not determine which rules of law were substantive and which were procedural. The Supreme Court's

14 See Swift v. Tyson, 41 U.S. (16 Pet.) 1 (1842) (holding that a federal court sitting in diversity need not apply New York substantive common law). Interestingly, the Swift Court noted that the New York rule was in a state of flux in the New York courts, "greatly shaken ... if not overthrown," id. at 17-18-suggesting that an attempt to find current state law might not have led to a different result and showing a sensitivity to concerns of federalism.

15 Erie, 304 U.S. at 74-75.

16 Id. at $73-75$ (discussing Black \& White Taxicab Co. v. Brown \& Yellow Taxicab Co., 276 U.S. 518 (1928)).

17 Id. at 74-75.

$18 \mathrm{Id}$. at $78-80$.

18 See id. at 79-80.

20 [E]xcept in matters governed by the Federal Constitution or by Acts of Congress, the law to be applied in any case is the law of the State. And whether the law of the state shall be declared by its Legislature in a statute or by its highest court in a decision is not a matter of federal concern.

Id. at 78 . 
most recent guidance on this question came in Hanna $v$. Plumer, ${ }^{21}$ which set forth a two-step process of decision. If a Federal Rule of Civil Procedure covers the matter and the rule is arguably procedural, the rule should be applied. ${ }^{22}$ In the absence of a federal rule, a diversity court should consider whether application of federal law would produce an outcome sufficiently different from the one a state court would render to offend the twin aims of Erie- "discouragement of forum shopping and avoidance of inequitable administration of the law."2s

The Court's test in Hanna was a retreat from the open-ended balancing approach pursued in Byrd v. Blue Ridge Rural Electric Cooperative. ${ }^{24}$ The Byrd Court began by asking to what extent the rule in question was an integral and substantial element of a state-created right. The Court then weighed the state interest in its rule against any contrary interests of the federal court system. ${ }^{25}$ Emphasizing that "[ $\left.t\right]$ he federal [court] system is an independent system for administering justice to litigants, ${ }^{326}$ the Court held that the distribution of responsibilities between judge and jury was an essential characteristic of the federal system and that " " $s]$ tate laws cannot alter the essential character or function of a federal court." "27

The Byrd balancing test was itself a reaction against the rigid version of outcome determination the Supreme Court originally adopted. ${ }^{28}$

21380 U.S. 460 (1965). For a narrative of the evolution from Erie to the present, see Ely, The Irrepressible Myth of Erie, 87 HARV. L. REv. 693, 694-97 (1974).

1s Hanna, 380 U.S. at 473-74.

28 Id. at 468 .

34356 U.S. 525 (1958). At issue in Byrd were contrary state and federal rules on whether judge or jury should decide a question of fact. The Court acknowledged that application of the federal rule might lead to a different outcome from the one litigants would receive in state court but found "affirmative countervailing considerations" in favor of the federal rule. Id. at 537 .

${ }_{25}$ The Court did not describe its holding as a balancing test, but later commentators have so characterized it. See, e.g., Ely, supra note 21, at 693, 696, 709.

28 Byrd, 356 U.S. at 537.

27 Id. at 539 (quoting Herron v. Southern Pac. Co., 283 U.S. 91, 94 (1931)).

28 The Court adopted the outcome determination test in Guaranty Trust Co. v. York, 326 U.S. 99 (1945). Faced with the question whether a statute of limitations was procedural or substantive, the Court held that the determinative criterion was whether the choice of federal law would substantially alter the outcome of the litigation. See id. at 109. Because the use of a different statute of limitations would have barred recovery, federal courts were bound to apply state law. Id. at 108-09.

The York Court strongly endorsed Erie's aim of uniformity of decision between state and federal courts. It described " $a$ federal court adjudicating a State-created right solely because of the diversity of citizenship of the parties" as "in effect, only another court of the State." Id. at 108. Suit brought "in a federal court instead of in a State court a block away should not lead to a substantially different result." Id. at 109.

The York outcome determination test held sway for over a decade. See, e.g., Ragan v. Merchants Transfer \& Warehouse Co., 337 U.S. 530, 532 (1949) ("It is conceded that if the present case were in a Kansas court it would be barred. The theory of [York] 
That approach, forbidding the application of federal law whenever it would affect the outcome, proved too extreme because, as the Court acknowledged in Hanna, ${ }^{29}$ nearly every variation in procedure might lead to a difference in outcome. The Byrd test in turn proved too indeterminate. Although the Hanna Gourt retained a version of outcome determination, Byrd's emphasis on countervailing federal interests has not been forgotten.

Courts currently apply a composite test, sifting through Erie and its progeny for guidance. ${ }^{80}$ Certainty is rare outside the refuge of the Federal Rules of Civil Procedure, but the relevant considerations can be specified. A federal court in diversity jurisdiction should act as another court of the state. The extent to which a rule is an integral element of a state-created right may be balanced against any contrary federal interests, although characteristics essential to an independent federal adjudication must not be compromised in the balance. The outcome of litigation should be sufficiently similar to discourage forum shopping and to avoid subjecting residents to inconsistent or conflicting judgments.

These factors can provide guidance for federal courts called upon to interpret uncertain state law. A federal court should seek to render the decision a state court would render. When an area of law is undergoing change in the lower state courts, a federal court will not achieve this goal by adhering to antiquated precedent from the state's highest court. Federal courts thus seriously misconstrue Erie when they conclude that Erie prohibits them from exercising independent judicial reasoning. Erie rather requires that federal courts use independent reasoning in searching for the rule of substantive law that the state's highest court would apply.

would therefore seem to bar it in the federal court.").

see 380 U.S. at 475.

${ }^{30}$ See, e.g., Hunt v. Liberty Lobby, Inc., 707 F.2d 1493, 1496-97 (D.C. Cir. 1983), in which the court carefully analyzed whether the res judicata effect of a judgment rendered by another federal court should be determined by state or federal law. The court weighed the requirements of Byrd, Hanna, and Guaranty Trust Co. v. York, 326 U.S. 99 (1945), as well as the possible effect of its decision on Erie's twin aims, concluding that Byrd's countervailing considerations precluded state law from nullifying the effect of a federal court judgment. Similar analyses can be found in Southern v. Plumb Tools, 696 F.2d 1321, 1323 (11th Cir. 1983); Yarber v. Allstate Ins. Co., 674 F.2d 232, 235 (4th Cir. 1982). The Third Circuit has attempted to distill Erie and its progeny into a single three-step test. First, the court evaluates any probable effect of the choice of law on the outcome; second, it determines the possible effect on forum shopping; third, it weighs federal interests against the state's interest in its rule. See Masino v. Outboard Marine Corp., 652 F.2d 330, 331-32 (3d Cir. 1982); Edelson v. Soricelli, 610 F.2d 131, 133, 137-38 (3d Cir. 1979). 


\section{B. The Determination of State Substantive Law}

When a federal court must apply unsettled state law as its rule of decision, it has few explicit sources of guidance outside the underlying purposes of Erie. The Supreme Court routinely denies certiorari to cases involving misinterpretations of state law by the federal courts, ${ }^{\mathbf{3 1}}$ and it has not directly addressed how federal courts ought to forecast changing state law since $1956 . .^{32}$ A federal court may sometimes avoid construing state law by certifying a question to the state's highest court or by abstaining from a decision, ${ }^{33}$ but these devices have serious drawbacks.

Certification increases the expense of litigation and adds to the volume of work facing state supreme courts without significantly diminishing the burden on federal courts. It requires the state court to render an advisory opinion in a case it is not adjudicating. ${ }^{34}$ Moreover, in approximately half of the states, including Pennsylvania, certification is not authorized, ${ }^{35}$ and the momentum for its enactment has died away. ${ }^{36}$

s1 Landes \& Posner, Legal Change, Judicial Behavior and the Diversity Jurisdiction, 9 J. Legal STud. 367, 373 (1980) ("[T] he Supreme Court rarely-if ever, in modern times-reviews diversity cases."); see also H. FRIENDLY, FEDERAL JuRISDICTION 141-42 \& n.11 (1973).

s2 See Bernhardt v. Polygraphic Co. of Am., 350 U.S. 198 (1956).

ss Certification permits federal courts to refer questions of state law to the state's highest court for resolution. Abstention permits federal courts to decline to exercise jurisdiction when faced with important questions of state law that have a substantial potential impact on the state.

s4 See generally R. Field, B. Kaplan \& K. Clermont, Materials for a Basic Course in Givil Procedure 202-03 (4th ed. 1978). Certification also delays litigation by an average of 15 months. Shapiro, Federal Diversity Jurisdiction: A Survey and a Proposal, 91 HARv. L. Rev. 317, 326-27 (1977).

If it were practicable, certification would be a nearly ideal solution to problems of forum shopping. The Supreme Court has expressly endorsed its use. See Clay v. Sun Ins. Office, 363 U.S. 207, 212 (1960) ("The Florida Legislature, with rare foresight, has dealt with the problem of authoritatively determining unresolved state law . . . by a statute which permits a federal court to certify such a doubtful question . . . to the Supreme Court of Florida for its decision."); see also Lehman Bros. v. Schein, 416 U.S. 386 (1974) (instructing Second Circuit to consider certification); Dresner v. City of Tallahassee, 375 U.S. 136 (1963) (certifying question to Florida Supreme Court).

3s At present, 23 states provide for certification. In 1967 the National Conference of Commissioners on Uniform State Laws passed a model statute authorizing certification. See Unif. Certification of Questions of LAW Acr, 12 U.L.A. 49 (1975). For a collection of cases and a listing of those states that have adopted a version of the Uniform Act either by statute or by appellate rule, see 12 U.L.A. 17-20 (Supp. 1984). This list excludes Maine and Hawaii, which have adopted rules not based on the Uniform Act. See 12 U.L.A. 50 (1975). See generally Note, Civil Procedure: Scope of Certification in Diversity Jurisdiction, 29 RUTGERS L. REv. 1155 (1976).

so The pace at which states have enacted laws or court rules permitting certification has dwindled over the last five years after extremely rapid expansion in the mid1970's. Only four states permitted certification in 1967, growing to 14 in 1975 and 21 
Abstention, alternatively, is an extraordinary remedy. Permitted only when the question at issue is likely to have a substantial impact on state interests, ${ }^{37}$ it runs contrary to the fundamental policy that courts may not decline the resolution of controversies over which they have jurisdiction..$^{38}$ As a practical matter, moreover, abstention is not neutral. It may be perceived as a verdict for the defendant, and it denies the plaintiff's right to a federal forum. More frequent use would undermine diversity jurisdiction.

In most instances, therefore, a federal court must reach a decision without the direct aid of state courts. Erie serves to remind courts of their accountability to state law and cautions against unbounded realization of the federal judiciary's own desires. But Erie does not forbid federal courts to participate in reforming state law when state courts are themselves rethinking it or when changes in other state doctrines indicate that state courts would rethink it if given the opportunity. Ideally, a federal court should anticipate the holding of the state's highest court. Can it best do so by refusing to recognize a new cause of action, or by looking to changed circumstances that warrant a departure from age-old precedent? If a federal court is to provide the same kind of adjudication that a state court would, it must look to new developments in the state's lower courts, to trends in analogous decisions of the state's highest court, and even, at times, to sources outside the state.

Unfortunately, federal courts tend not to use independent judgment when called upon to apply state law. For example, the Internal Operating Procedures of the Third Circuit do not allow one panel to reverse a prior panel's interpretation of state law unless an intervening state supreme court decision has clearly announced change. ${ }^{38}$ Because district courts are bound by Third Circuit decisions, no federal court in the circuit may recognize a change in state law until it is announced by the state's supreme court. Although on a superficial level strict adherence to the decisions of the state supreme court seems to effect compli-

in 1980 . Since then only two additional states have approved certification. This slowdown seems to be due to the infrequency with which certification is used. See 12 U.L.A. 50 (1975); id. at 17-20 (Supp. 1984).

37 See Colorado River Water Conservation Dist. v. United States, 424 U.S. 800, 814 (1976); Louisiana Power \& Light Co. v. City of Thibodaux, 360 U.S. 25 (1959). For an example of abstention in an employment at will discharge controversy, see Boniuk v. New York Medical College, 353 F. Supp. 1353, 1355 (S.D.N.Y.), affd mem., 714 F.2d 111 (2d Cir. 1982).

${ }_{38}$ See, e.g., Cohens v. Virginia, 19 U.S. (6 Wheat.) 264, 404 (1821) ("With whatever doubts, with whatever difficulties, a case may be attended, we must decide it, if it be brought before us. We have no more right to decline the exercise of jurisdiction which is given, than to usurp that which is not given.") (Marshall, C.J.).

so See supra note 6. 
ance with Erie, a federal court can hardly be said to be dispensing the same justice as the state court "a block away"40 if it thus abdicates its adjudicative function. The few Supreme Court precedents in the area support the view that when dealing with state law, federal courts should use "judicial brains, not a pair of scissors and a paste-pot."11

Supreme Court opinions written soon after Erie expressed the view that federal courts should behave exactly like state courts, reexamining the law when a state court would have done so. ${ }^{.2}$ Federal courts, however, sought to retain some of their earlier authority by deciding with complete independence those issues not definitively resolved by the highest court of the forum state. ${ }^{43}$ To put an end to this trend, the Supreme Court issued several decisions declaring that federal courts were strictly bound by earlier state decisions-those of lower state courts as well as those of the state's highest court. ${ }^{44}$

Although these cases can be read to require that a federal court behave like an automaton, ${ }^{45}$ their holdings must be understood in light of their purpose to put an end to "the confusion and injustices arising from inconsistent federal and state interpretations on state law."'46 These cases do not mandate a wooden application of Erie. For example, in West $v$. American Telephone E Telegraph Co., ${ }^{17}$ the Court declared that in the absence of a clear directive from the state's highest court, federal courts must look to other sources within the state rather than create their own rules of law. The West opinion directed federal courts "to ascertain from all available data what the state law is and apply it rather than to prescribe a different rule, however superior it may appear." 48 Decisions of an intermediate state court were "not to be

10 Guaranty Trust Co. v. York, 326 U.S. 99, 109 (1945).

11 Corbin, The Laws of the Several States, 50 YALE L.J. 763, 775 (1941).

12 See Wichita Royalty Co. v. City Nat'l Bank, 306 U.S. 103, 107 (1939) ("[I]t was [the federal court's] duty to apply the Texas law as the Texas court would have declared and applied it on a second appeal if the cause had not been removed. . . . [The federal court was] free to depart from earlier rulings to the extent that examination of later opinions of the Texas Supreme Court showed that it had modified its opinion on the first appeal."); Ruhlin v. New York Life Ins. Co., 304 U.S. 202, 209 (1938) ("Now [the federal courts] must merely broaden their inquiry to include decisions of the state courts, and just as they would in a case tried in the state court ....").

1s See, e.g., West v. American Tel. \& Tel. Co., 311 U.S. 223, 235 (1940); see also Kurland, Mr. Justice Frankfurter, the Supreme Court, and the Erie Doctrine in Diversity Cases, 67 YaLE L.J. 187, 205-06 (1957).

4 See, e.g., Fidelity Union Trust Co. v. Field, 311 U.S. 169 (1940).

15 See Kurland, supra note 43 , at 206-11. Kurland also calls this approach "mechanical jurisprudence." Id. at 209.

10 Vandenbark v. Owens-Illinois Glass Co., 311 U.S. 538, 543 (1941).

17311 U.S. 223 (1940).

$48 \mathrm{Id}$. at 237. 
disregarded by a federal court unless it is convinced by other persuasive data that the highest court of the state would decide otherwise." line drawn here is subtle: federal courts may not substitute their independent judgment for that of state courts, yet they must evaluate changing trends and intermediate court opinions to predict the state supreme court's present posture.

The leading Supreme Court case on federal courts' determination of state law remains Bernhardt v. Polygraphic Co. of America. ${ }^{50}$ Bernhardt held that the effect of an arbitration clause must be determined under Vermont law: the underlying contractual right at issue was statecreated and therefore could not be altered by federal courts. ${ }^{61}$ The Court divided, however, on what Vermont law was. The majority deferred to the district court's finding that the governing precedent was a 1910 Vermont Supreme Court case holding arbitration agreements nonbinding. ${ }^{52}$ Justice Frankfurter argued that the case should be remanded for consideration of whether state law had changed in the intervening forty-six years, even though the change was not reflected in a decision of the state's highest court. ${ }^{\mathbf{3}}$

Justice Frankfurter's concurrence urged that federal courts actively adjudicate rather than passively apply antiquated precedent:

As long as there is diversity jurisdiction, "estimates" are necessarily often all that federal courts can make in ascertaining what the state court would rule to be its law. . . . [The] mere fact that Vermont in 1910 restated its old law . . . is hardly a conclusive ground for attributing to the Vermont Supreme Court application of this equitable doctrine in 1956 ... . Law does change with times and circumstances, and not merely through legislative reforms. . . . The attitude reflected by that decision nearly half a century ago was the current traditional judicial hostility against ousting courts, as the phrase ran, of their jurisdiction..

Surely in light of all that has happened since 1910 in the general field of the law of arbitration, it is not for us to

${ }^{49}$ Id. Accord Six Co. v. Joint Highway Dist. No. 13, 311 U.S. 180, 181-83 (1940) ("[It] makes little difference what state court has declared the law so long as it is the rule of decision in the state."); Fidelity Union Trust Co. v. Field, 311 U.S. 169, 177-78 (1940) ("[W] here the state law supplies the rule of decision, [federal courts must] ascertain and apply that law even though it has not been expounded by the highest court of the State.") (footnote omitted).

o 350 U.S. 198 (1956).

81 See id. at 202-04.

52 See id. at 204-05.

${ }^{63}$ See id. at 209-12. 
assume that [Vermont law is unchanged]. ${ }^{54}$

Bernhardt thus suggests that federal courts may not draw from precedents or sources of law outside the state, nor may they use independent judgment to evaluate or revise substantive state law. Old precedents must be left untouched absent clear portents of change. In practice, federal courts show a strong reluctance to reappraise state law or announce change. ${ }^{5 \mathrm{~B}}$ Bound both by the highest and the intermediate state courts, a federal judge in a diversity case has been described as a mere "ventriloquist's dummy," forbidden to innovate or to extend the law.

Bernhardt's deference to state law expressed the Court's resolve to prevent the federal judiciary from ignoring state law. Bernhardt was, moreover, a product of the strict version of outcome determination then in force. At that time, the Court discouraged independent analysis and extraterritorial sources of law on the same grounds that it required even traditionally procedural issues to be left to state law when federal law might produce a different outcome. The rigidity of this deference to state law was the means by which an insistent Supreme Court conveyed its message to federal judges reluctant to yield their independent domains to state control.

But the view of the majority in Bernhardt is not so deferential to state precedent as some have taken it to be. Bernhardt involved an area of law in which there had been no indication of change within the state, either by the courts or by the legislature. The majority found "no confusion in the authorities that casts a shadow over the established ones, no dicta, doubts or ambiguities in the opinions of Vermont judges on the question, no legislative development that promises to undermine the judicial rule. We see no reason, therefore, to remand the case . . . ."37 It is a fair implication that if there had been any clue that Vermont law was changing, the majority would have remanded despite the forty-sixyear-old supreme court precedent.

Even if Bernhardt does support rigid adherence to outdated precedent, however, its current force is mitigated by the subsequent changes Byrd and Hanna have brought to the underlying Erie doctrine. Federal courts must now make their decisions in light of the underlying aims of Erie. A mechanical rule would not further those aims. Certainly, rigid enforcement of an old precedent despite indications that state courts

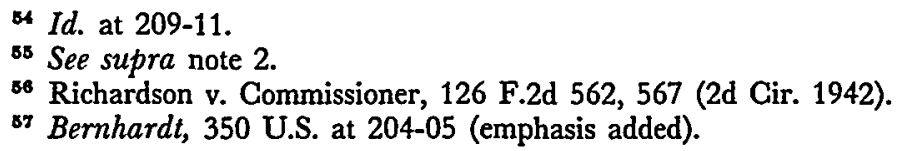


would discard it can produce both forum shopping and inequitable administration of the laws. To ascertain how state courts would currently rule, federal courts must be free to rethink the last state precedent, to draw from dicta and from holdings of lower state courts although the supreme court may once have addressed the issue, even to look to sources outside the state boundaries. In short, they must proceed in the same manner as an intermediate state court.

\section{The Inherent Nature of Change in the Common Law}

This section develops jurisprudential arguments that independent analysis and critical reappraisal of precedent are essential to sound adjudication. Change and adaptation are inherent virtues of the common law. To suggest that federal courts may not extend or modify state law is not only to give litigants a different form of justice from that available in state courts but is to repudiate the very essence of judicially created law. Even if this course were wise, it would not be possible-for even the refusal to change has consequences. ${ }^{58}$ Each use or avoidance of precedent influences subsequent applications by expanding, constricting, or reinforcing previous law.

Of course, there can be little hope of proving these propositions. The persuasive force of jurisprudential argument seems to depend largely on the extent to which premises and prejudices are shared before the argument is made. The positivist is unlikely to persuade the realist, and neither is likely to win the economist's assent. Yet each of these schools has accepted and found value in the tendency of common law rules to adapt over time. This section collects support for the above propositions from various schools of thought in the hope that at least one will be aligned with the reader's own perceptions.

Legal realists deny that law can be distilled from precedent and applied to new fact patterns with scientific or logical rigor. Rather, they perceive law as responding primarily to the economic and political climate. For the realists, therefore, it is a truism that the common law adapts to changing social and economic conditions. ${ }^{8 \theta}$ As Justice Car-

sB See L. Fuller, The Law in Quest of Itself 40-41 (1940) ("The judge makes law even when he states that he is refusing to make it.").

${ }^{59}$ Epstein, The Static Conception of the Common Law, 9 J. LEgal STUd. 253, 253 (1980); Gordon, Historicism in Legal Scholarship, 90 YALE L.J. 1017, 1029 n.43 (1981) ("Adaptation theory is so pervasive in the scholarship of the past two centuries that it would be a challenge to find a work in which it was not present."). For leading examples of the view that law responds to socioeconomic exigencies, see, e.g., L. FrIEDman, History of american Law (1973); M. Horwitz, The Transformation of American LaW (1977). See generally A. Watson, Society and Legal Change 7-8, 130-37 (1977). 
dozo stated, "The rules and principles of case law have never been treated as final truths, but as working hypotheses, continually retested ... . Every new case is an experiment; and if the accepted rule which seems applicable yields a result which is felt to be unjust, the rule is reconsidered." $" 60$

Legal positivists, too, acknowledge that any legal system requires a degree of flexibility in order successfully to resolve a wide variety of problems in a continually changing context. ${ }^{61}$ H.L.A. Hart bases this assessment on the simple human inability to predict the future. ${ }^{62}$ Neither precedent nor legislation can formulate a rule that will do justice in all future circumstances. The unenvisaged case is inevitable, and therefore "[i]n every legal system, a large and important field is left open for the exercise of discretion by courts ... in developing and qualifying rules only broadly communicated by authoritative precedent." ${ }^{\text {"63 }}$ More fundamentally, Hart argues that language itself is necessarily indeterminate. Even the clearest expression of a legal rule leaves a degree of ambiguity that can be resolved only through an interpretation of underlying policies. ${ }^{64}$

Those who validate law in economic terms also acknowledge that change and independent judgment are essential. Judge Posner and others who believe that the common law gravitates toward economic efficiency have theorized that it does so primarily because of the behavior of litigants. ${ }^{\text {bs }}$ If judges do not decide cases on the basis of economic efficiency, then economically efficient and inefficient decisions are made randomly. Because there is a greater economic incentive for litigants to

60 B. Gardozo, The Nature of the Judicial Process 23 (1921) [hereinafter cited as B. Gardozo, Judicial Process]. See also B. Cardozo, The Growth of THE LAW 69-70, 73 (1924) ("We may frame our conclusions for convenience as universal propositions. We are to remember that in truth they are working hypotheses.").

-1 Any legal system, to remain viable over a span of time, must have the flexibility to admit change. To find solutions for a succession of differing problems in a continually changing context, it must be creative. On the other hand, a group of institutions and their methods of operation cannot constitute a system in the absence of strong elements of stability and predictability. Creativity must build upon a solid foundation of continuity.

Keeton, Creative Continuity in the Law of Torts, 75 Harv. L. Rev. 463, 463 (1962).

os See H.L.A. HART, The Concept of LAw 132 (1972); see also id. at 124-27.

ss Id. at 132 .

se See at 121-27.

os See, e.g., R. Posner, Economic ANalysis of Law (2d ed. 1977); Goodman, An Economic Theory of the Evolution of the Common Law, 7 J. LEGAL STUD. 393 (1978); Landes \& Posner, Adjudication as a Private Good, 8 J. Legal STud. 235 (1979); Priest, The Common Law Process and the Selection of Efficient Rules, $6 \mathrm{~J}$. Legal STUd. 65 (1977); Rubin, Why Is the Common Law Efficient?, 6 J. LEGAL STud. 51 (1977). See generally Change in the Common Law: Legal and Economic Perspectives, 9 J. LegaI StUd. 189 (1980) (symposium). 
undertake the expense of challenging economically inefficient results, ${ }^{66}$ inefficient rules will be attacked more often than efficient ones. Over time, this will increase the percentage of efficient rules left standing. ${ }^{67}$ If judges never depart from precedent, however, repeated challenges to inefficient rules will not alter the results: the original percentages will merely be perpetuated. ${ }^{88}$ Thus even the economists' vision of progress toward a corpus of efficient legal rules assumes that judges will reconsider earlier, inefficient holdings.

This consensus among divergent schools underscores the fact that evolution is an essential attribute of the common law. Unlike statutes, court decisions have only persuasive force for like cases in the future. ${ }^{69}$ The decision in a case binds only the parties and is rooted in the policies and equities of its moment. ${ }^{70}$ Not just the facts of the case but also the social mores and the state of the law at the time the decision is rendered contribute to its very meaning. Each application of precedent alters that meaning. Even the application of a well-established rule ex-

68 Although this assumption seems harmless enough and even intuitively attractive, several objections may be raised. For example, it is unlikely that judges do decide cases randomly with regard to efficiency. Cases that make adjustments for inequitable bargaining power may well be decided in a manner exactly contrary to efficiency. Similarly, there is a greater incentive for plaintiffs to sue wealthy defendants. Assuming that free market forces will channel wealth to the most productive entities, the most efficient users of resources will most often be challenged. For an interesting rebuttal of Posner, see Dworkin, Is Wealth A Value?, 9 J. LEGAL STUD. 191 (1980) (arguing that maximization of social wealth is not and should not be the function of courts).

${ }^{67}$ An illustration may be helpful. Of 100 cases, suppose 50 are decided efficiently and 50 are not. Suppose further that litigants challenge 50 of these 100 decisions in new litigation, but-because the litigants are likelier to challenge inefficient results-they challenge 30 of the original 50 inefficient cases and only 20 of the efficient ones. Suppose, finally, that courts again decide half these cases efficiently and half inefficiently. The second round of litigation will leave $30+25=55$ efficient rules standing and only $20+25=45$ inefficient rules standing. This example is taken from Priest, supra note 65, at 68-69.

e8 A variation on the numerical example in note 67 illustrates such a perpetuation of inefficient rules. If courts are unwilling to reconsider precedent, the second round of decisions will not be independent of the first. Bound by the original 100 decisions, courts will decide the 30 relitigated inefficient cases in the same way, leaving $30+20$ $=50$ inefficient precedents. To the extent that change is permitted in state courts but avoided in federal courts, the process of improvement will continue, but at a much more gradual rate.

69 Corbin, supra note 41, at 772 ("The decision binds the litigants. It binds nobody else. ... [I]ts rationalizations are not legislative enactments, general in application. They are merely "persuasive data." ").

70 [E]very doctrine has its foundations in policy considerations of one kind or another, whether explicit or not. . . .

.. . [P]olicy considerations are interwoven into the fabric of the doctrine itself. One who undertakes to interpret doctrine and to apply it independently of attention to the policy considerations that are associated with its creative decisional development misunderstands the doctrine itself.

Keeton; supra note 61 , at 470. 
pands slightly the list of different fact patterns to which it applies. ${ }^{71}$ More importantly, each application revitalizes the precedent, indicating that the rule remains appropriate for the present day and state. ${ }^{72}$ It is therefore wrong to suppose that a court chooses between change and stasis. Whether it follows earlier holdings or abandons them, a court affects the state of the law.

For this reason, the application of an earlier decision should never be mechanical. ${ }^{78}$ The policies and equities that created the precedent should be reexamined in the context of each subsequent application. Founded equally on social policy and particular controversies, doctrine must alter as policies and circumstances alter. ${ }^{74}$ As Professor Corbin argued in an article written shortly after Erie and West were decided,

All rules of law are for the courts to apply-yes; but all rules of law are also for the courts to change ... . These changes and these applications should indeed not depend upon the accident of diversity of citizenship.

Where ... a party is forced into federal court, it is reasonable to hold that his rights should be determined in accordance with the same system of law as would have been applied had the case been in a state court.

Therefore, when the forum is a federal court, that court must determine the applicable law by recourse to all the ju-

71 Every precedent ... has a "directive force for future cases of the same or similar nature." . . . Once declared, it is a new stock of descent. It is charged with vital power. It is the source from which new principles or norms may spring to shape sentences thereafter. . . . [I]t is one of the living forces of our law.

B. Cardozo, Judictal Process, supra note 60, at 21-22 (quoting Redlich, The Case Method in American Law Schools, Bulletin No. 8, Carnegie Foundation, at 37). See also H.L.A. HART, supra note 62, at 126 (explaining that each application of a rule further clarifies its meaning, purpose, and scope).

72 For example, the Pennsylvania Supreme Court has cited a federal district court's use of an 83-year-old precedent as evidence of its continued vitality. See Geary v. United States Steel Corp., 456 Pa. 171, 175, 319 A.2d 174, 176 (1974) (citing McKinney v. Armco Steel Corp., 270 F. Supp. 360, 362 (W.D. Pa. 1967) (applying Henry v. Pittsburgh \& L.E.R.R., 139 Pa. 289, 21 A. 157 (1891))).

78 H.L.A. HART, supra note 62, at 125; see B. CARdozo, Judicial Process, supra note 60, at 20-21 (law cannot evolve by mere process of comparing instant case to precedents). See generally K.N. Llewellyn, The Common Law TRadition: DECIDING APPEALS 62-120 (1960) (listing 64 ways in which judges extend, restrict, or circumvent precedent in deciding appeals).

74 Keeton, supra note 61 , at 470-72 (only a focus on the competing forces that brought the doctrine about will guide its application to a subsequent judgment); Wellington, Common Law Rules and Constitutional Double Standards: Some Notes on Adjudication, 83 YALE L.J. 221, 225 (1973) ("The [legal] profession generally recognizes that it is an obligation of the courts to justify the rules they announce and to keep the rules and their justifications up to date."). 
ristic data that are available to the state court. If the federal judge is required to discard some of those available data, the litigant is not getting the same justice that he would get if the forum were a court of the state . . . .

Our judicial process is not mere syllogistic deduction, except at its worst. At its best, it is the wise and experienced use of many sources in combination-statutes, judicial opinions, treatises, prevailing mores, custom, business practices .... Shall a litigant . . . be deprived of the advantages of this judicial process? ${ }^{78}$

\section{The Interplay Between State and Federal Courts In Evolving Exceptions to the Employment at Will Doctrine in Pennsylvania}

The history of the employment at will doctrine in Pennsylvania offers an excellent example of the interplay between state and federal courts in an area of rapidly changing law. Ten years ago the employment at will doctrine was virtually unchallenged. Today at least half of the states have created exceptions. ${ }^{76}$ Pennsylvania's Supreme Court welcomed reform in the very first wave of change, ${ }^{77}$ but only in dictum: it has never held that the doctrine is modified or abolished in Pennsylvania. Lower Pennsylvania courts have embraced reform, but federal courts have shown an unwillingness to recognize this change. Because federal courts have not been guided by developments in the lower state courts, they are enforcing a distinctly different version of the law. Indeed, the federal courts, often following federal precedent in the absence of later pronouncements by the Pennsylvania Supreme Court, have developed an approach unknown in Pennsylvania law at any period. Ironically, then, an overly literal interpretation of Erie Railroad

78 Corbin, supra note 41 , at $772-75$.

70 See Summers, Introduction, Individual Rights in the Workplace: The Employment-At-Will Issue, 16 U. MICH. J.L. REF. 201, 203 (1983) ("For a hundred years the employment at will doctrine was unbending and seemed to go unchallenged; in ten years it has largely disintegrated and is now under frontal attack."); see also infra notes 93-95 and accompanying text.

The literature on employment at will is vast. For recent bibliographies, see $U_{N}$ just Dismissal 1983: Litigating, Setrtling and Avoiding Claims 117-28 (J. Barbash \& J. Kauff eds. 1983) [hereinafter cited as UNJUST Dismissal]; Decker, AtWill Employment in Pennsylvania-A Proposal for its Abolition and Statutory Regulation, 87 DICK. L. REv. 477, 477 n.3 (1983); Note, Protecting Employees at Will Against Wrongful Discharge: The Public Policy Exception, 96 HaRv. L. REv. 1931 (1983).

77 See Geary v. United States Steel Corp., 456 Pa. 171, 319 A.2d 174 (1974). 
v. Tompkins ${ }^{78}$ has yielded federal common law-the very kind of law that Erie condemned.

After describing the original employment at will doctrine and the reform it has undergone throughout the United States, this section examines the changes that Pennsylvania courts have introduced in the area and contrasts the intransigence of the federal courts. It then considers the further discrepancy between state and federal law wrought by purely federal additions to the law of wrongful discharge.

\section{A. Nationwide Changes in the Doctrine of Employment at Will}

The employment at will doctrine permits discharge for any or no reason from employment not covered by a contract of explicit duration. ${ }^{79}$ No notice or explanation is required. The doctrine's initial ac-

78304 U.S. 64 (1938).

${ }^{9}$ See generally Note, Protecting At Will Employees Against Wrongful Discharge: The Duty to Terminate Only in Good Faith, 93 HARv. L. REv. 1816 (1980) [hereinafter cited as Note, Protecting At Will Employees]. Neither custom in the trade nor a contract that clearly implies but does not require a specific term of employment suffices to overcome the presumption that employment is at will. Similarly, an offer of "permanent" employment or employment for life is considered too indefinite to provide a valid term and therefore is also deemed to be at will. Note, Protecting At Will Employees, supra, at 1816. The doctrine is applicable to approximately $60 \%$ of the American workforce. See Note, supra note 3, at 389 \& n.1.

Discharges for reprehensible reasons have often been upheld. See, e.g., Hinrichs v. Tranquilaire Hosp., 352 So. 2d 1130 (Ala. 1977) (discharge for refusal to falsify medical records); Tameny v. Atlantic Richfield Co., 88 Cal. App. 3d 646, 152 Cal. Rptr. 52 (1979) (discharge for refusal to participate in price fixing scheme), rev'd, $27 \mathrm{Cal}$. 3d 167 (1980); Martin v. Platt, 179 Ind. App. 688, 386 N.E.2d 1026 (1979) (discharge for reporting kickback payments received by superior). See generally Note, Protecting At Will Employees, supra, at 1816-17. Courts have held that discharge even for a morally bad cause is-legally acceptable. See Payne v. Western \& Atl. R.R., 81 Tenn. 507, 51819 (1884).

Surprisingly, the origins of the doctrine of employment at will are not in English common law. See Summers, Individual Protection Against Unjust Dismissal: Time for a Statute, 62 VA. L. REv. 481, 485 (1976). In fact, America seems to be the only industrialized nation to have such a doctrine. Id. at 508-19; see also Summers, supra note 76, at 203-04. Of 126 countries, the United States was the only member of the International Labor Organization to vote against a convention on termination of employment in 1982. Bellace, A Right of Fair Dismissal: Enforcing a Statutory Guarantee, 16 U. MrCh. J.L. REF. 207, 210-18 (1983).

English law presumed employment for a year's term and required notice customary in the trade. Feinman, The Development of the Employment at Will Rule, 20 AM. J. Legal Hist. 118, 119-21 (1976); Note, The Employment at Will Rule: The Development of Exceptions and Pennsylvania's Response, 21 DuQ. L. REv. 477, 478-80 (1983) [hereinafter cited as Note, Pennsylvania's Response]; Note, Implied Contract Rights to Job Security, 26 STAN. L. REv. 335, 340 (1974) [hereinafter cited as Note, Implied Contract Rights]; see Summers, supra, at 485. Earlier English and American law held the master responsible for the health and welfare of her servant. See Note, Protecting At Will Employees, supra, at 1824. Blackstone justified the English rule on the equitable grounds that one ought not be able to hire a worker only in harvest and 
ceptance has been attributed to the Supreme Court's unwillingness to interfere with "liberty of contract" or with the employer's fifth amendment property right in the employee's labor. ${ }^{80}$ There was a perceived mutuality between the employee's freedom to quit without notice and the employer's ability to discharge. ${ }^{81}$ The doctrine was also justified by characterizing the employment relation as a unilateral offer by the employer, accepted continuously by the employee's labor but capable of withdrawal at any time. ${ }^{82}$

Since the beginnings of the labor movement, the attitudes on which the doctrine was based have seen numerous changes. ${ }^{83}$ Legislative acts have curtailed the employer's unbridled power over the employee, ${ }^{84}$ and the emergence of collective bargaining has shown that such power is not essential to our economic system. Approximately twenty percent of the workforce is covered by collective bargaining agreements, and ninety percent of these agreements limit the employer's right of arbi-

planting seasons, discharging her at less productive times. See $1 \mathrm{~W}$. BLackstone, COMMENTARIES ON THE LAWS OF ENGLAND *425-26.

${ }_{80}$ The origin of the doctrine in America has been attributed to an ill-supported statement in a widely respected legal treatise, H. WOOD, MASTER AND SERVANT $\S$ 134 , at 272-73 (1877). For a discussion of the four cases on which Wood relied and an argument that these cases neither supported him nor reflected the true state of the doctrine in the United States, see Note, Pennsylvania's Response, supra note 79, at 480 nn.18-20; Note, Implied Contract Rights, supra note 79, at 341-42 \& n.54.

The Supreme Court's refusal to invade employment relationships is exemplified by Lochner v. New York, 198 U.S. 45 (1905), in which the Court invalidated a state law setting a 10-hour daily maximum and a 60-hour weekly maximum for bakers' working hours. The Court maintained its deferential attitude toward employers in the period following the Lochner decision. See, e.g., Coppage v. Kansas, 236 U.S. 1, 17 (1915); Adair v. United States, 208 U.S. 161, 172 (1908); see also Summers, supra note 79, at 485-86; Note, Protecting At Will Employees, supra note 79, at 1826.

${ }^{81}$ The employee's labor is seen as consideration only for wages. Additional consideration must be shown for any promise of a guaranteed term of employment. Note, Pennsylvania's Response, supra note 79, at 480 n.26; Note, Protecting At Will Employees, supra note 79, at 1818-19 (collecting cases).

${ }_{82}$ Note, Protecting At Will Employees, supra note 79, at 1818-19. For an example of this attitude in a recent Pennsylvania case, see, e.g., Wagner v. Sperry Univac, 458 F. Supp. 505, 520 (E.D. Pa. 1978), affd mem., 624 F.2d 1092 (3d Cir. 1980). 491-93.

ss See generally Summers, supra note 76, at 203-04; Summers, supra note 79, at

84 See, e.g., Employee Retirement Income Security Act of 1974, Pub. L. No. 93 $406, \S 2,88$ Stat. 829,833 (codified in scattered sections of $5,18,26,29,31$ \& 42 U.S.C.) (protecting employee retirement benefits); Occupational Safety and Health Act of 1970, Pub. L. No. 91-596, 84 Stat. 1590 (codified in scattered sections of 5, 18, 26, 29, 31 \& 42 U.S.C.) (protecting employees from unsafe working conditions); National Labor Relations Act of 1935, 29 U.S.C. $\$ \S 151-169$ (1982) (authorizing unionization); Fair Labor Standards Act of 1938, 29 U.S.C. $\$ \S 201-219$ (1982) (minimum wage); Title VII, Civil Rights Act of 1964, 42 U.S.C. $\$ 2000 \mathrm{e}-2$ (1982) (prohibiting discrimination in hiring on basis of race, creed, or sex). For a fuller listing of legislative enactments limiting the employer's right to control employees, see Note, Protecting At Will Employees, supra note 79, at $1827 \mathrm{nn}$. 63-67. 
trary discharge. ${ }^{85}$ Another eleven percent of the workforce is covered by the "just cause" limitation of the civil service regulations. ${ }^{86}$ Courts have begun to recognize the disparity between the stake an employee has in her livelihood and the interest an employer has in arbitrary discharge. ${ }^{\mathbf{8 7}}$ In general, the attitude that originally protected the employer from any state interference has long since disappeared. ${ }^{88}$

Change in the doctrine, however, came only recently. The first case to uphold a cause of action for wrongful discharge, decided in $\mathrm{Cal}$ ifornia in 1959, involved an employee fired for refusing to commit perjury. ${ }^{88}$ In 1973 Indiana's Supreme Court extended a cause of action to an employee fired for filing a worker's compensation claim..$^{90}$ And in 1974 , in the leading case of Monge v. Beebe Rubber Co., ${ }^{91}$ the New Hampshire Supreme Court upheld an action by a woman discharged for refusing her supervisor's sexual advances. The New Hampshire court took the longest strides, holding that unjustified discharges were unlawful as contrary to the state's economic interests. ${ }^{92}$

The pace of change began to accelerate in the late 1970 's. ${ }^{93}$ Current estimates of the number of states with exceptions to the employment at will doctrine vary from twenty-one to thirty-four. ${ }^{94}$ More sig-

${ }^{85}$ Note, Protecting At Will Employees, supra note 79, at 1832 n.89.

se See 5 U.S.C. \$7513(a) (1982).

s7 See, e.g., Yaindl v. Ingersoll-Rand Co., 281 Pa. Super. 560, 573-76, 583, 422 A.2d 611, 618-19, 623 (1980).

88 The Supreme Court long ago abandoned the posture of extreme restraint manifested in Lochner v. New York, 198 U.S. 45 (1905). See, e.g., Phelps Dodge Corp. v. NLRB, 313 U.S. 177, 187 (1941); NLRB v. Jones \& Laughlin Steel Corp., 301 U.S. 1 (1937); West Coast Hotel Co. v. Parrish, 300 U.S. 379 (1937); Nebbia v. New York, 291 U.S. 502 (1934). The Supreme Court has even gone so far as to recognize due process rights in cases of unjust discharge from government employment. See, e.g., Perry v. Sindermann, 408 U.S. 593 (1972); Board of Regents v. Roth, 408 U.S. 564 (1972).

see Petermann v. International Bhd. of Teamsters, Local 396, 174 Gal. App. 2d 184, 344 P.2d 25 (1959).

${ }^{90}$ See Frampton v. Central Ind. Gas Co., 260 Ind. 249, 297 N.E.2d 425 (1973).

01114 N.H. 130, 316 A.2d 549 (1974).

92 See id. at 133, 316 A.2d at 551-52. But see infra note 105 (discussing New Hampshire's retreat).

${ }^{93}$ See Peck, Unjust Discharges from Employment: A Necessary Change in the Law, 40 Oнго ST. L.J. 1, 1-2 (1979).

o4 See Note, supra note 3 , at 394 n.29 (counting 29 states as having recognized exceptions and five others as having acknowledged the possibility of exceptions in certain circumstances). For a collection of wrongful discharge cases from all 50 states, see Wrongful Discharge: Employment at Will, 1 LABOR RELATIONS EXPEDITER (BNA) 939-87 (Aug. 1, 1983) (counting 21 states as recognizing public policy exceptions and 13 as recognizing implied contracts in employee handbooks) [hereinafter cited as Wrongful Discharge]. See generally UnJust DisMIsSal, supra note 76; DeGiuseppe, The Effect of the Employment-at-Will Rule on Employee Rights to Job Security and Fringe Benefits, 10 FordhaM URB. L.J. 1 (1982) (discussing implied contract and public policy exceptions). 
nificantly, of the thirty-six state supreme courts that have addressed the issue directly in the last decade, twenty-five have created exceptions to the traditional doctrine. ${ }^{95}$

Several legal theories have emerged to justify and delimit the extent of those exceptions. The mildest and most commonly accepted theory admits the employer's right to arbitrary discharge with a single caveat prohibiting discharges for reasons contrary to public policy. ${ }^{96}$ Unless the discharge affects the integrity of the legal system, such as a discharge for accepting jury duty or refusing to perjure, ${ }^{97}$ the public policy exception is usually limited to policies that find expression in a statute or other legislative source. ${ }^{98}$ The next most frequently accepted theory is one of implied contract, found either in the behavior of the parties or in the terms of employee handbooks and personnel manuals. ${ }^{99}$ The court may hold the employer to the terms of the manual ${ }^{100}$ or having found an implied contract may impute such additional terms as employment for a reasonable time ${ }^{101}$ or a requirement of good faith termination. ${ }^{102}$ Although it is of more recent origin, approximately half the states that recognize exceptions to employment at will have adopted this theory. ${ }^{103}$ The most progressive theories adopt a duty of good faith or a requirement of just cause in all terminations, ${ }^{104}$ a course few states have followed. ${ }^{108}$

os See Note, supra note 76, at 1931 \& n.4; see also Wrongful Discharge, supra note 94 (stating that 24 of the 40 highest state courts to consider the employment at will doctrine in the last six years have created exceptions); $c f$. Note, supra note 76 , at 1931 ("A veritable avalanche of scholarly opinion has, with near unanimity, come down in favor of abolishing the at will rule.").

- See Note, Pennsylvania's Response, supra note 79, at 493-96.

97 See e.g., Petermann v. International Bhd. of Teamsters, Local 369, $174 \mathrm{Cal}$. App. 2d 184, 344 P.2d 25 (1959); Nees v. Hocks, 272 Or. 210, 536 P.2d 512 (1975) (en banc); Reuther v. Fowler \& Williams, Inc., 255 Pa. Super. 28, 386 A.2d 119 (1978). (1982).

93 See, e.g., Brockemayer v. Dun \& Bradstreet, 109 Wis. 2d 44, 324 N.W.2d 70

${ }_{99}$ See, e.g., Hepp v. Lockheed-California Co., 86 Cal. App. 3d 714, 150 Cal. Rptr. 408 (1978); Toussaint v. Blue Cross \& Blue Shield, 408 Mich. 579, 292 N.W.2d 880 (1980).

${ }_{100}$ See, e.g., Jackson v. Minidoka Irrigation Dist., 98 Idaho 330, 563 P.2d 54 (1977); Toussaint v. Blue Gross \& Blue Shield, 408 Mich. 579, 292 N.W.2d 880 (1980).

101 See Note, Implied Contract Rights, supra note 79, at 358-59.

102 See, e.g., Gleary v. American Airlines, 111 Cal. App. 3d 443, 168 Cal. Rptr. 722 (1980); Fortune v. National Cash Register Co., 373 Mass. 96, 364 N.E.2d 1251 (1977).

103 See Wrongful Discharge, supra note 94, at 940.

104 See, e.g., Monge v. Beebe Rubber Co., 114 N.H. 130, 316 F.2d 549 (1974). But see infra note 105 .

${ }_{108}$ Massachusetts, Alaska, Oregon, and Montana have taken this route. See Wrongful Discharge, supra note 94, at 940-87. Pennsylvania state superior courts have 
Legal theories are still coalescing as courts freely mix various contract and policy theories. ${ }^{108}$ The trend toward liberalization of the strict doctrine of employment at will, however, is unmistakable. And the courts of Pennsylvania have been receptive to this wave of reform.

\section{B. The Doctrine in Pennsylvania State Courts}

Henry v. Pittsburgh $\mathcal{E}^{\circ}$ Lake Erie Railroad ${ }^{107}$ best expresses the classic employment at will doctrine in Pennsylvania. Affirming nonsuit, the judge held that an employer "may discharge an employee with or without cause, at pleasure, unless restrained by some contract; . . . I do not see that the questions of malice and want of probable cause have anything to do with the case."108 The Pennsylvania Supreme Court followed this principle without exception, ${ }^{109}$ citing it in dicta until 1959. ${ }^{110}$ Since then the court has addressed the doctrine only once, in Geary v. United States Steel Corp. ${ }^{111}$

Geary, a salesman and an employee at will of fourteen years, believed that the steel tubing he was selling had been inadequately tested and might be unsafe. Although he sold the tubing as instructed, he was discharged for insubordination after expressing his concerns to management. The tubing was eventually taken off the market. Geary brought

developed a test that amounts to a just cause requirement. See Yaindl v. Ingersoll-Rand Co., $281 \mathrm{~Pa}$. Super. 560, 422 A.2d 611 (1980); see also infra text accompanying notes 132-38.

Some states have enacted statutes requiring employers to show just cause for termination where the employment is for a specified period of time. See ARK. STAT. ANN. $\S 81-310$ (1976); S.D. Codified LAws ANN. § 60-4-5 (1978). Puerto Rico requires just cause even where the period of employment is not specified. See P.R. LAws ANN. tit. 29, § 185(a)-(b) (Supp. 1983).

New Hampshire, meanwhile, has drawn back from its holding in Monge that all dismissals must be for just cause. It has construed Monge to apply only to situations where an employee is discharged because she performed an act that public policy would encourage or refused to perform an act that public policy would condemn. See Clouthier v. Great Atl. \& Pac. Tea Co., 121 N.H. 915, 436 A.2d 1140 (1981); Howard v. Dorr Woolen Co., 120 N.H. 295, 414 A.2d 1273 (1980).

108 See generally Note, Protecting At Will Employees, supra note 79, at 1818-24.

$107139 \mathrm{~Pa} .289,21$ A. 157 (1891) (ticket agent discharged without good reason in the course of an investigation into embezzlement).

108 Id. at $297,21 \mathrm{~A}$. at 157.

108 See, e.g., Cummings v. Kelling Nut Co., 368 Pa. 448, 451, 84 A.2d 323, 325 (1949) (representations of anticipated success do not create promise of employment over period of time); Polk v. Steel Workers Organizing Comm., $360 \mathrm{~Pa} .631,634,62$ A.2d 850,852 (1949) (employee may be discharged for refusing to join union); Trainer v. Laird, $320 \mathrm{~Pa}$. 414, 415, $183 \mathrm{~A}$. 40, 40 (1936) (contract fixing compensation annually does not defeat employment at will presumption).

110 See, e.g., Linn v. Employers Reinsurance Corp., 397 Pa. 152, 157-58, 153 A.2d 483, 485 (1959).

11456 Pa. 171, 319 A.2d 174 (1974). 
an action for wrongful discharge, in which he claimed to have acted only in the interests of public safety.

Geary's claim was weak at best. His discharge affronted no explicit legislative policy. The record showed almost no support for his assertion that the pipe was hazardous. Geary had no training or expertise that could justify his evaluation of technical specifications, and he had violated company policy by appealing to senior management over his immediate supervisors. Despite these facts, the court split four-tothree in refusing to recognize a cause of action.

The split appears to have been less on principle than on whether this particular case should be the fulcrum for change. Both the majority and the dissent agreed that reform was desirable, but only the dissent found the time and case to be at hand. ${ }^{112}$ The dissent argued that a threat to public safety, if demonstrated, would sufficiently implicate public policy to support a challenge to the discharge. ${ }^{113}$ The majority, however, citing a federal district court case, found that the Henry rule was still accepted as valid law ${ }^{114}$ and was in accord with the weight of authority elsewhere. ${ }^{115}$.

The majority feared uncharted territory: it felt that an overruling of the established doctrine would be too great a shock to employment relations. ${ }^{116}$ Nonetheless, the majority warmly supported reform in dicta. Beginning with a lengthy and approving discussion of the nascent public policy exception to the employment at will doctrine, the majority acknowledged that economic conditions had changed significantly from

112 See id. at 193-94, 319 A.2d at 185.

118 See id. at 187,319 A.2d at 181.

116 See id. at 175, 319 A.2d at 176 (citing McKenney v. Armco Steel Corp., 270 F. Supp. 360 (W.D. Pa. 1967)). Such state court reliance on federal diversity cases suggests that the Erie model, which envisions law as created by state courts and applied by federal courts, is too simplistic. Each court system relies on the other in times of change or uncertainty, and each contributes to the formation of the common law.

${ }_{115}$ See id. at 175-76 \& nn.4-5, 319 A.2d at $176 \&$ nn.4-5. The court cited $\$ 762$ of the Restatement of Torts and 53 AM. JUR. 2D Master $\mathcal{E}$ Servant $\$ \S 34,43$ (1970) ("The employer enjoys an absolute power of dismissing his employee without cause."). The cited portion of American Jurisprudence refers one to American Law Reports, which in 1975 was still able to state that "few legal principles would seem to be better settled than [the principle that] an employment for an indefinite term is regarded as an employment at will which may be terminated at any time by either party for any reason or for no reason at all." Annot., 62 A.L.R.3D 271, 271 (1975).

If the court were to look to the same sources of authority today, it would find a different approach. The Restatement section has been deleted. See RESTATEMENT (SECOND) OF TORTS $\S 762$ (1979). The same section of American Jurisprudence lists 41 cases from 22 jurisdictions upholding exceptions to the doctrine. 53 AM. JUR. 2D Master EO Servant \& 43 (Supp. 1984).

116 See Geary, $456 \mathrm{~Pa}$. at 175, 319 A.2d at 175-76 (quoting Henry, $139 \mathrm{~Pa}$. at 297,21 A. at 157). 
the time of Henry. ${ }^{117}$ The Geary court quoted at length from a seminal law review article hostile to the doctrine ${ }^{\mathbf{1 1 8}}$ and paraphrased the New Hampshire Supreme Court's Monge decision. Although the Geary court questioned whether the time had come for judicial reform, ${ }^{110}$ it agreed that the doctrine must be restricted. ${ }^{120}$ The court examined the two existing legal theories that might have justified an exception to the doctrine. Finding neither a tort theory of malicious discharge nor a statutorily recognized public policy applicable to the facts, ${ }^{121}$ the majority was careful to conclude that "it is not necessary to reject the rationale of these decisions in order to defend the result we reach here."122

To appreciate the significance of Geary, one must remember that Geary was among the first five cases in the country to admit even the possibility of an exception to the doctrine of employment at will. ${ }^{123}$ In extrapolating from Geary to ascertain what the Pennsylvania Supreme Court would decide today, one must apply its reasoning to present circumstances. Despite the weakness of the plaintiff's case, three of the seven justices would have granted a cause of action. Admittedly, a majority of the court declined to recognize the action, but their treatment of the doctrine was extremely progressive compared to that of other states at the time. It may fairly be inferred that on better suited facts the court would have recognized such exceptions to the doctrine as then existed. Other legal theories that might have fit Geary's case better than the theories then available were not yet developed. ${ }^{124}$ Moreover, the majority in Geary based its holding partly on its reluctance to diverge radically from a nationally accepted body of law and the expecta-

117 See id. at 176, 319 A.2d at 176.

118 See id. (quoting Blades, Employment at Will vs. Individual Freedom: On Limiting the Abusive Exercise of Employer Power, 67 Colum. L. REv. 1404 (1967)).

110 See id. at 177,319 A.2d at 176-77.

130 See id. at 184,319 A.2d at 180.

121 See id. at 177-83, 319 A.2d at 177-80.

122 Id. at 183 n.16, 319 A.2d at 180 n.16.

123 The four earlier cases are Snyder v. Regents of the Univ. of Cal., 33 Cal. App. 3d 977, 109 Cal. Rptr. 506 (1973); Petermann v. International Bhd. of Teamsters, Local 396, 174 Cal. App. 2d 184, 344 P.2d 25 (1959); Frampton v. Central Ind. Gas Co., 260 Ind. 249, 297 N.E.2d 425 (1973); Monge v. Beebe Rubber Co., 114 N.H. 130, 316 A.2d 549 (1974).

124 Federal courts have interpreted Geary to hold that no other exceptions to the doctrine exist in Pennsylvania. See infra note 142. But given the Geary court's reliance on factors that have changed, its aggressiveness compared to other state courts at the time, and the extent to which it reached out to discuss questions not essential to the case, it is likely that the court would have endorsed exceptions that have emerged since Geary. See supra note 115. In particular, the court did not reach the theory that employee handbooks may be taken as implied contracts. Although no court at the time had accepted such a theory, it is now the law in 13 states. See Wrongful Discharge, supra note 94 , at 940 . 
tions of employers. ${ }^{128}$ Given the rapid trend of subsequent change, a desire to conform to national standards would augur a contrary result today.

In the ten years since Geary, seven Pennsylvania superior courts and four lower courts have decided wrongful discharge cases. ${ }^{126}$ All credited Geary with establishing a cause of action. ${ }^{127}$ The state courts have moved beyond Geary's dicta: one court has held that an employment manual may constitute an implied contract, ${ }^{128}$ while another, in effect, has introduced a requirement of just cause for termination of employment. ${ }^{129}$

The first state decision to apply Geary embraced the public policy exception. In Reuther $v$. Fowler $\mathcal{E}^{2}$ Williams, Inc. ${ }^{190}$ an employee was allegedly discharged for accepting jury service. The court found that Geary, together with precedent from other states, justified a cause of action. ${ }^{191}$

Two years later, in Yaindl v. Ingersoll-Rand Co., ${ }^{132}$ the superior court adopted a very progressive test. The employer's privilege, it said, was no longer absolute: "it exists in the context of, and must sometimes yield to, other interests including the interest of the employee in making a living, and the interest of the public in seeing to it that the employer does not act abusively."13s Yaindl held that courts "must weigh several factors, balancing against the appellant's interest in making a living, his

12s See $456 \mathrm{~Pa}$. at 184-85, 319 A.2d at 180.

${ }^{128}$ See Cisco v. United Parcel Servs., 476 A.2d 1340 (Pa. Super. 1984); Banas v. Matthews Int'l Corp., No. 1205 (Pa. Super. June 15, 1984); Richardson v. Charles Cole Memorial Hosp., 466 A.2d 1084 (Pa. Super. 1983); Sacks v. Commonwealth, 465 A.2d 981 (Pa. Super. 1983) (public employment); Yaindl v. Ingersoll-Rand Co., 281 Pa. Super. 560, 422 A.2d 611 (1980); Hunter v. Port Auth., 277 Pa. Super. 4, 419 A.2d 631 (1980) (public employment); Reuther v. Fowler \& Williams, Inc., 255 Pa. Super. 28, 386 A.2d 119 (1978); Turner v. Letterkenny Fed. Gredit Union, No. 198266 (Pa. Commw. Ct. Aug. 14, 1984); Cuccaro v. United States Steel Corp., 131 Pitt. L.J. 534 (1983); Grundon v. Defense Activities Fed. Credit Union, 33 Comb. Co. L.J. 529 (1983); Butler v. Negley House, Inc., 129 Pitt. L.J. 350 (1981).

${ }_{127}$ Decisions denying a cause of action did so because no public policy was implicated. The courts did not doubt that Geary announced a change in the law. See Cisco v. United Parcel Servs., Inc., 476 A.2d 1340, 1341 (Pa. Super. 1984); Richardson v. Charles Cole Memorial Hosp., 466 A.2d 1084, 1085 (Pa. Super. 1983). This position is in marked contrast to federal interpretations, which for many years read Geary as leaving the employment at will doctrine unchanged. The federal courts still interpret Geary in this way occasionally. See infra note 142.

${ }_{128}$ See Banas v. Matthews Int'l Corp., No. 1205 (Pa. Super. June 15, 1984).

129 See Yaindl v. Ingersoll-Rand Co., 281 Pa. Super. 560, 422 A.2d 611 (1980), discussed infra text accompanying notes 132-38.

130255 Pa. Super. 28, 386 A.2d 119 (1978).

131 See id. at 30, 386 A.2d at 120 (citing, e.g., Nees v. Hocks, 272 Or. 210, 536

P.2d 512 (1975) (holding discharge for accepting jury service unlawful)).

132281 Pa. Super. 560, 422 A.2d 611 (1980).

133 Id. at $571-72,422 \mathrm{~A} .2 \mathrm{~d}$ at 617 . 
employer's interest in running its business, its motive in discharging appellant and its manner of effecting the discharge, and any social interests or public policies that may be implicated in the discharge."134 Applying this test, the court found that no public policy was implicated and that the decision to discharge had received an independent good faith review by a senior company official. These facts suggested that the discharge was valid. ${ }^{135}$

Although the Yaindl court based its discussion on the public policy exception created by Geary, its reading of public policy was expansive, recognizing that " $a$ discharge motivated by bad faith or malice or based on retaliation is not in the best interest of the economic system."136 The Yaindl standard goes considerably beyond the more commonly recognized "statutorily based public policy" exception, in effect establishing a just cause requirement. An employee's interest in her livelihood will usually seem stronger than an employer's interest in any nonproductive arbitrary discharge. ${ }^{137}$ Furthermore, a discharge for reasons other than just cause will tend to affront the public interest in economic efficiency ${ }^{138}$ or to reveal motives unacceptable to the court. Consequently, any discharge other than for just cause should tip the balance of the Yaindl test in favor of the employee.

Yaindl is not the only case to have taken an approach even more progressive than the one suggested in the Geary dicta. Recently, in Banas v. Matthews International Corp., ${ }^{139}$ a Pennsylvania superior court held that "a manual published or authorized by an employer and distributed to an employee-at-will becomes part of the parties' employment contract"140 and that deviation from its terms can justify an action

1s4 Id. at $577,422 \mathrm{~A} .2 \mathrm{~d}$ at 620 .

${ }^{135}$ Id. at $578-80,422 \mathrm{~A} .2 \mathrm{~d}$ at $620-21$.

${ }^{138} \mathrm{Id}$. at 573 n.5, 422 A.2d at 618 n.5 (citing Monge). Geary acknowledged two possible causes of action-a traditional tort action for malicious discharge and a public policy exception. Judge Spaeth interpreted the tort action as a special feature of the broad public policy exception because malicious discharge was not in the public interest.

${ }_{187}$ See, e.g., Yaindl, 281 Pa. Super. at 584, 422 A.2d at 623-24 ("The law . . . accords little, if any, weight to the vindictive spirit, but it accords great weight to the individual's right to earn a living.").

138 See, e.g., Monge, 114 N.H. at 133, 316 A.2d at 551-52.

130 No. 1205 (Pa. Super. June 15, 1984).

140 Banas, slip op. at 13. Banas was an at-will employee of 20 years who made bronze tombstones. The manual authorized employees to use scrap metal for personal jobs if they received permission from their supervisor. Banas received permission to make a tombstone for his nephew. A management memorandum seen only by supervisors directed that employees not be permitted to make tombstones on their own as it interfered with business relations between the company and the cemeteries it supplied. When the tombstone was discovered, Banas was fired. A jury awarded him $\$ 10,000$ for breach of contract and $\$ 40,000$ for defamation and punitive damages because, at his 
by the employee in assumpsit for breach of contract. Banas, like Geary, Yaindl, and other Pennsylvania cases, shows a strong desire to reform the law, reaching out beyond the facts to adopt theories as liberal as any accepted by other states. ${ }^{141}$

dismissal, his supervisor called him a thief. On appeal, the superior court vacated and remanded the defamation award but affirmed the breach of contract verdict.

The superior court characterized the at-will employment relation as a unilateral offer continuously accepted by the employee's labor. The employment manual becomes a part of the employer's offer when it is issued; it is accepted by the employee's continued work. The employer may change or rescind the manual at any time. If the employee shows up for work the next day, she has accepted the altered terms.

Although the court gathered some support from Pennsylvania law for attaching significance to employee manuals, the cornerstone of its holding is its recognition of change outside the state. See Banas, slip op. at $11 \mathrm{n} .5$ (citing precedent from nine other states).

141 Two Pennsylvania cases since Geary have refused to allow a wrongful discharge claim. The first Pennsylvania case to consider the question of the contractual force of employee manuals, Richardson v. Charles Cole Memorial Hosp., 466 A.2d 1084 (Pa. Super. 1983), reached a conclusion opposite to Banas. Richardson, a director of nursing, was fired without just cause after four years' employment. A clause in his employee manual provided that the hospital's policy was to continue employment as long as work was performed satisfactorily. The court held that the policies set forth in the employee handbook did not constitute part of the Richardson's contract of employment. The policies were gratuitous benefits, unilaterally extended by the employer and unenforceable by the employee.

Federal courts in Pennsylvania had already denied the contractual force of employee manuals three times before the decision in Richardson. See Rogers v. International Business Machines Corp., 500 F. Supp. 867 (W.D. Pa. 1980) (manual too vague); Beidler v. W.R. Grace, Inc., 461 F. Supp. 1013, 1016 (E.D. Pa. 1978) ("[F]ailure to adhere to company personnel policy does not create a cause of action for breach of an employment contract."), aff d mem., 609 F.2d 500 (3d Cir. 1979); Wagner v. Sperry Univac, 458 F. Supp. 505, 519-21 (E.D. Pa. 1978) (summary judgment precluded by genuine issue of fact regarding whether employer actually breached contract), affd mem., 624 F.2d 1092 (3d Cir. 1980). Although the question had never been resolved by a Pennsylvania state court, the Richardson court cited Beidler to support the statement that Pennsylvania did not acknowledge implied contracts. See Richardson, 466 A.2d at 1085. Given the federal judiciary's cautious attitude toward altering state law, such reliance by a state court on federal precedent seems rather ironic. As the Banas court noted, the precedent on which Richardson relied has been substantially weakened. See Banas, slip op. at 9 n.4.

The other state case since Geary to have denied a cause of action for wrongful discharge is Cisco v. United Parcel Servs., Inc., 476 A.2d 1340 (Pa. Super. 1984). A customer charged a deliveryman with theft. While charges were pending, United Parcel Services forced the deliveryman to resign. He brought his wrongful discharge case when the company refused to reinstate him after his acquittal. Id. at 1341. Although the court upheld dismissal of the claim, it acknowledged the existence of a wrongful discharge action in Pennsylvania, crediting its origin to Geary. Id. Reviewing the trilogy of Reuther, Yaindl, and Hunter v. Port Auth., 277 Pa. Super. 4, 419 A.2d 631 (1980), the court reiterated the Yaindl balancing test, concluding that these cases mandated a "thorough review of the circumstances surrounding a discharge of an at-will employee." Cisco, 476 A.2d at 1343. The court concluded that no public policy was violated where the employer's reputation was threatened by the mere accusation of a job-related crime and where the employer fired the employee to protect its reputation. See id. at 1344. 


\section{Federal Court Interpretations}

Under Erie, federal courts should be sensitive to emerging state law, echoing the changes made and anticipating those foreshadowed by state courts. The federal courts' interpretation of Pennsylvania's employment at will doctrine, however, contrasts sharply with state developments.

Federal courts in Pennsylvania have resolved unjust discharge cases thirty-seven times since Geary. In contrast to the five out of seven state cases recognizing an action, the federal courts have upheld a cause of action for wrongful discharge only nine times. ${ }^{142}$ The reluctance of

The Cisco court interpreted Geary and its progeny as requiring a two-part test. First, a court must ask whether any public policy is threatened; second, it must ask whether the employer had "separate, plausible and legitimate reasons" for the discharge. Id. at 1343 . This test, however, seems inappropriate for summary judgment. If a public policy is implicated and the employer contends that a permissible alternative motive led to the discharge, then the decision depends on a factual determination of the employer's true motive. The existence of this factual issue should cause the claim to survive a motion for dismissal or summary judgment. This was exactly the situation presented in Reuther and the rationale on which summary judgment was denied.

Moreover, the Cisco court's test is dangerous insofar as it suggests that a discharge that violates public policy might nevertheless be insulated by an innocent alternative rationale. Employee terminations are complex and are often susceptible to different explanations. If an alternate reason can defeat a public policy violation, the public policy exception seems likely to lose all force.

142 The following cases have dismissed wrongful discharge actions or granted summary judgment for defendant: Wolk v. Saks Fifth Avenue, Inc., 728 F.2d 221 (3d Cir. 1984) (sexual harassment claim preempted by statutory remedy); Bruffett v. Warner Communications, Inc., 692 F.2d 910 (3d Cir. 1982) (termination allegedly because of physical handicap that did not affect job performance); Bonham v. Dresser Indus., Inc., 569 F.2d 187 (3d Cir. 1977) (age discrimination), cert. denied, 439 U.S. 821 (1978); Kamens v. Summit Stainless, Inc., No. 83-3644 (E.D. Pa. Mar. 29, 1984) (age discrimination claim preempted by statute); Buckmon v. Wilmington Dry Goods Store, No. 82-1167 (E.D. Pa. Feb. 6, 1984) (alleged violation of public policy); Adams v. Budd Co., 583 F. Supp. 711 (E.D. Pa. 1984) (implied contract and public policy claims); Ruch v. Strawbridge \& Clothier, Inc., 567 F. Supp. 1078 (E.D. Pa. 1983) (alleged breach of terms of personnel manual); Shaffer v. National Can Corp., 565 F. Supp. 909 (E.D. Pa. 1983) (sexual harassment claim preempted by statutory remedy); Harrison v. Fred S. James, P.A., Inc., 558 F. Supp. 438 (E.D. Pa. 1983) (alleged breach of implied contract); Madreperla v. Williard Co., No. 82-3505 (E.D. Pa. Dec. 17, 1982) (public policy violation); Shaw v. Russell Trucking Line, 542 F. Supp. 776 (W.D. Pa. 1982) (discharge for refusing to drive overloaded trucks; motion to dismiss allowed, but plaintiff given leave to amend complaint); Callahan v. Scott Paper Co., 541 F. Supp. 49 (E.D. Pa. 1982) (discharge for refusal to participate in price fixing); Wood v. Burlington Indus., 536 F. Supp. 56 (E.D. Pa. 1981) (alleged oral contract for permanent employment); Boreson v. Rohm \& Haas, 526 F. Supp. 1230 (E.D. Pa. 1981) (discharge for unsatisfactory performance), affd, 729 F.2d 1445 (3d Cir. 1984); Huff v. County of Butler, 524 F. Supp. 751 (W.D. Pa. 1981) (discharge for alleged sexual harassment); Fleming v. Mack Trucks, Inc., 508 F. Supp. 917 (E.D. Pa. 1981) (alleged discharge for disclosing embezzlement); Moorhouse v. Boeing Co., $501 \mathrm{~F}$. Supp. 390 (E.D. Pa.) (alleged oral contract for permanent employment), affd, 639 F.2d 774 (3d Cir. 1980); Rogers v. International Business Machines Corp., 500 F. 
federal courts to countenance change has led them to invent strands of doctrine alien to state law.

\section{Federal Court Interpretations Prior to Novosel}

In the four years following Geary, only federal courts found occasion to interpret Pennsylvania's employment at will doctrine. None accorded any weight to Geary's dicta; all relied instead on earlier cases. Two federal decisions granted summary judgment without any mention of Geary, ${ }^{143}$ while two others cited it for the proposition that Pennsylvania "recently reaffirmed the employment at will doctrine."144

Supp. 867 (E.D. Pa. 1980) (discharge contrary to employee manual); Lekich v. International Business Machines Corp., 469 F. Supp. 485 (E.D. Pa. 1979) (bad faith); Beidler v. W.R. Grace, Inc., 461 F. Supp. 1013 (E.D. Pa. 1978) (discharge contrary to personnel manual), affd mem., 609 F.2d 500 (1979); Walker v. University of Pittsburgh, 457 F. Supp. 1000 (W.D. Pa. 1978) (discharge allegedly for exercising right to free speech); O'Neill v. A.R.A. Servs., Inc., 457 F. Supp. 182 (E.D. Pa. 1978) (discharge in bad faith and contrary to public policy); Wehr v. Burroughs Corp., $438 \mathrm{~F}$. Supp. 1052 (E.D. Pa. 1977) (age discrimination); Geib v. Alan Wood Steel Co., 419 F. Supp. 1205 (E.D. Pa. 1976) (implied contract); Keddie v. Pennsylvania State Univ., 412 F. Supp. 1264 (M.D. Pa. 1976) (public policy and first amendment); Green v. Medford Knitwear Mills, 408 F. Supp. 577 (E.D. Pa. 1976) (implied contract).

Even after Yaindl, federal courts have refused at times to see that Pennsylvania would allow any exception at all to the classical employment at will doctrine. See Wells v. Thomas, 569 F. Supp. 426, 432 (E.D. Pa. 1983) ("Pennsylvania has neither recognized nor advanced . . . challenges to the traditional doctrine (of employment at will]."); Jenkins v. United Steel Workers of Am., 522 F. Supp. 80, 85 (E.D. Pa. 1981) (expressing doubt as to whether a tort of wrongful discharge exists in Pennsylvania).

Only the following federal cases have recognized wrongful discharge actions: Novosel v. Nationwide Ins. Co., 721 F.2d 894 (3d Cir. 1983) (public policy and implied contract); Perks v. Firestone Tire \& Rubber Co., 611 F.2d 1363 (3d Cir. 1979) (discharge on basis of polygraph test); Karr v. Township of Lower Merion, $582 \mathrm{~F}$. Supp. 410 (E.D. Pa. 1983) (public policy); Rettinger v. American Can Co., 574 F. Supp. 306 (M.D. Pa. 1983) (discharge because of disability and filing of worker's compensation claim); Molush v. Orkin Extermination Co., 547 F. Supp. 54 (E.D. Pa. 1982) (discharge on basis of polygraph test); Forman v. BRI Corp., 532 F. Supp. 49 (E.D. Pa. 1982) (alleged hiring for reasonable time); McNulty v. Borden, Inc., $474 \mathrm{~F}$. Supp. 1111 (E.D. Pa. 1979) (discharge for refusing to participate in price fixing); Wagner v. Sperry Univac, 458 F. Supp. 505 (E.D. Pa. 1978) (discharge contrary to employment manual); McGinley v. Burroughs Corp., 407 F. Supp. 903 (E.D. Pa. 1976) (rationale unrelated to Geary reasoning).

143 See Keddie v. Pennsylvania State Univ., 412 F. Supp. 1264, 1278 (M.D. Pa. 1976); Green v. Medford Knitwear Mills, 408 F. Supp. 577 (E.D. Pa. 1976).

144 See Walker v. University of Pittsburgh, 457 F. Supp. 1000, 1002 (W.D. Pa 1978); Geib v. Alan Wood Steel Co., 419 F. Supp. 1205, 1207 (E.D. Pa. 1976).

One case, McGinley v. Burroughs Corp., 407 F. Supp. 903 (E.D. Pa. 1975), did uphold an action for discharge contrary to public policy, but did so without mention of Geary, on the novel rationale that any contract, including a "contract at will," that is breached in contravention of public policy creates a cause of action. $407 \mathrm{~F}$. Supp. at 910. But the employment at will relationship was not a contract under traditional doctrine. With this exception, all eight federal court cases that followed Geary and preceded Reuther refused to recognize a cause of action for wrongful discharge. See supra 
The first federal case to recognize Geary's message interpreted it with remarkable narrowness and in effect devised a test to avoid its application. Wehr v. Burroughs Corp. ${ }^{145}$ involved a discharge allegedly in violation of a statement in the Pennsylvania Human Relations Act ${ }^{146}$ (PHRA) that age discrimination in employment is contrary to public policy. ${ }^{147}$ Although the Wehr court acknowledged Geary's statement that an action might lie when a discharge violated a statutorily expressed public policy, it held that a common law action could not be brought if the statute already carried a remedy for the violation. ${ }^{148} \mathrm{Be}-$ cause the PHRA provided for a remedy, the court dismissed Wehr's action. The Third Circuit adopted Wehr's restriction when it addressed the wrongful discharge question for the first time, in Bonham $v$. Dresser Industries, Inc. ${ }^{149}$ a case presenting another instance of age discrimination. The court held that under Pennsylvania law the PHRA provided the exclusive remedy for a violation of its policies. ${ }^{150}$

The "no alternative remedy" test does not appear in Pennsylvania cases, nor can it be deduced from their reasoning. Indeed, it is paradoxical in light of the emerging state law: Geary's dicta require that the public policy be statutorily recognized, but any statute that declares an explicit policy is likely to carry its own remedy, thereby forestalling a wrongful discharge action under Wehr and Bonham. The "no alternative remedy" test, then, is a purely federal invention.

Even after the aggressive state holding in Yaindl, federal courts have recognized wrongful discharge actions only rarely. ${ }^{181}$ When they have, they have interpreted the action narrowly, unlike the state courts, ${ }^{162}$ and kept the "no alternative remedy" test alive. ${ }^{153}$ One expla-

note 142 .

148438 F. Supp. 1052 (E.D. Pa. 1977).

${ }^{146}$ PA. Stat. AnN. tit. 43, §§ 951-963 (Purdon 1964 \& Supp. 1984-85).

147 The PHRA provides:

It is hereby declared to be the public policy of this Commonwealth to foster the employment of all individuals in accordance with their fullest capacities regardless of their race, color, . . . handicap or disability, . . . age, sex, or national origin, and to safeguard their right to obtain and hold employment without such discrimination . . . .

Pa. Stat. Ann. tit. 43, § 952(b) (Purdon Supp. 1984-85).

148 See Wehr, 438 F. Supp. at 1055-56.

149569 F.2d 187 (3d Cir. 1977), cert. denied, 439 U.S. 821 (1978).

100 See id. at 195. But see infra notes 160-61 and accompanying text.

161 See supra note 142 and accompanying text.

${ }^{162}$ Compare, e.g., Yaindl v. Ingersoll-Rand Co., 281 Pa. Super. 560, 577, 422 A.2d 611, 620 (1980) with, e.g., Bruffett v. Warner Communications, Inc., 692 F.2d 910, 918-19 (3d Cir.॰1982).

:Bs This test formed the rationale of the Third Circuit's most recent denial of a wrongful discharge claim. See Wolk v. Saks Fifth Avenue, Inc., 728 F.2d 221 (3d Cir. 1984); see also Bruffett v. Warner Communications, Inc., 692 F.2d 910, 915-20 (3d 
nation is the strong tendency of federal courts, even in diversity matters, to rely on federal precedent rather than state cases. ${ }^{154}$ Such reliance is misplaced under any interpretation of Erie. To a degree, of course, federal courts are bound by prior holdings and must be mindful of reversal by higher federal courts. The clear dictate of Erie, however, is that federal courts apply state law in diversity actions. When state law is changing, Erie requires that federal courts be sensitive to that trend. Until the state law becomes settled, federal courts should approach each case afresh, undertaking a search for state law at that moment, and not relying on prior federal interpretations. Federal courts' failure to reappraise their own precedents in the face of new holdings by lower state courts and dicta by the state supreme court is a violation of the spirit of Erie.

\section{The Conflict Between Bruffett, Novosel, and Wolk}

Federal courts applying Pennsylvania law have not been uniformly insensitive to state developments in the doctrine of employment at will. This has led to a substantial discrepancy of result within the Third Circuit in the cases of Bruffett $v$. Warner Communications, Inc. ${ }^{165}$ and Novosel v. Nationwide Insurance Co. ${ }^{156}$

Bruffett involved termination of temporary employment and withdrawal of a permanent job offer because of a physical handicap that did not affect the employee's performance. ${ }^{157}$ Such a discharge is contrary to the public policy of Pennsylvania as expressed in the PHRA. ${ }^{158}$ After finding that the employment was at will, the Third Circuit held that under Bonham the existence of a remedy in the PHRA precluded a wrongful discharge action. Permitting recovery would give plaintiffs an opportunity to avoid the "carefully drafted legislative procedures"

Cir. 1982).

154 A study by Landes and Posner found that federal courts applying state law are two and one-half times more likely to cite federal precedent than to cite state precedent and concluded that "state courts cite mainly state cases and federal courts mainly federal cases." Landes \& Posner, supra note 31, at 374-75. This pattern is instrumental in slowing federal recognition of change in state law. See, e.g., Wells v. Thomas, 569 F. Supp. 426, 432 (E.D. Pa. 1983) (citing federal cases and finding that Pennsylvania law recognizes only a narrow exception to the employment at will doctrine):

158692 F.2d 910 (3d Cir. 1982).

156721 F.2d 894 (3d Cir. 1983).

167 Bruffett was hired temporarily, then offered permanent employment on the condition that he pass a routine medical exam. The exam disclosed Bruffett's diabetes, which in no way affected his work. The job offer was withdrawn and his temporary position eliminated.

${ }^{168}$ See supra note 147. 
that circumscribed the PHRA's remedies. ${ }^{159}$ The court did recognize that in Fye v. Central Transportation, Inc., ${ }^{160}$ a case decided after Bonham, the Pennsylvania Supreme Gourt held that the PHRA precluded other remedies only when invoked; ${ }^{\mathbf{1 6 1}}$ it also recognized that Bruffett had not invoked the PHRA. Nonetheless, the court held that the existence of an unexercised and nonexclusive alternative remedy precluded a wrongful discharge action. The court found this test consistent with Pennsylvania law, arguing that in the only cases admitting exceptions to the employment at will doctrine there was no alternative remedy. ${ }^{162}$ This is not so. ${ }^{163}$

The Bruffett opinion is an instance of the federal courts' unwillingness to recognize change in state law. It viewed the Geary court's rejection of the plaintiff's cause of action as "placing Pennsylvania with those states which have viewed the public policy exception in a more constricted fashion."164 The Bruffett court relied on the fallacious view ${ }^{185}$ that in refusing to recognize new causes of action it was not influencing state law. "One of the authentic obligations of federalism at the judicial level," the court said, "requires that we permit the state courts to decide whether and to what extent they will follow the emerging law."168

In sharp contrast to Bruffett, the court in Novosel adopted an expansive interpretation of exceptions to the employment at will doctrine in Pennsylvania. Novosel, an insurance company employee for fifteen

130 Bruffett, 692 F.2d at 919.

180487 Pa. 137, 409 A.2d 2 (1979).

161 See id. at 140-41, 409 A.2d at 4. This reasoning follows the plain meaning of the PHRA, which states that it "shall, when invoked, be exclusive." PA. STAT. ANN. tit. 43, \& 962(b) (Purdon Supp. 1984-1985) (emphasis added).

${ }^{162}$ See 692 F.2d at 919.

${ }^{283}$ See, e.g., Reuther, $255 \mathrm{~Pa}$. Super. 28, 386 A.2d 119 (upholding cause of action for employee discharged for performing jury duty). Although not discussed in the opinion, 42 PA. Cons. STAt. ANN. \$ 4563 (Purdon Supp. 1984-1985) authorizes an employee to bring suit for reinstatement and back pay against an employer who dismisses her because of jury duty.

The "no alternative remedy" test is also at odds with earlier federal holdings. In Davis v. United States Steel Corp., 581 F.2d 335, 340-41, vacated on other grounds en banc, 688 F.2d 166 (3d Cir. 1982), cert. denied, 460 U.S. 1014 (1983), the Third Circuit acknowledged a cause of action for wrongful discharge in addition to a remedy under 42 U.S.C. $\S 1981$ (1982). And in McNulty v. Borden, Inc., 474 F. Supp. 1111 (E.D. Pa. 1979), a district court upheld both a right of action under the Glayton Act, 15 U.S.C. $\$ \S 12-27$ (1982), and a separate action for discharge in violation of public policy.

164 Bruffett, 692 F.2d at 919. This statement is simply inaccurate, given Pennsylvania's aggressive position relative to other states at the time Geary was decided, to say nothing of the later expansion of Geary's reasoning in Reuther and Yaindl.

${ }^{105}$ See supra notes 71-73 and accompanying text.

168692 F.2d at 920. 
years, was discharged when he refused to assist his employer's lobbying for the elimination of no-fault auto insurance. The court allowed both a tort claim for discharge against public policy and an implied contract claim based on company practice and personnel policies. ${ }^{\mathbf{1 6 7}}$

The Novosel court noted the substantial erosion of employment at will nationwide: twenty-nine states had admitted exceptions to the doctrine, and six others had indicated their willingness to do so. ${ }^{168}$ It was against this background that the court analyzed Geary, paying less attention to federal interpretations than to state trends. The court concluded that Pennsylvania would recognize a cause of action for a discharge that violated a clear mandate of public policy. ${ }^{169}$ In its search for public policy the court endeavored to reach the same result as a state court. The Novosel court decided that

an important public policy is in fact implicated wherever the power to hire and fire is utilized to dictate the terms of employee political activities .... While there are no Pennsylvania cases squarely on point, we believe that the clear direction of the opinions promulgated by the state's courts suggests [that they would uphold a cause of action]. ${ }^{170}$

The Novosel opinion directed that the district court on remand apply the Yaindl balancing test to determine if the employee's interest in free speech and a livelihood outweighed whatever impairment might be shown to the employer's interests.

Novosel's analysis of the employment at will doctrine is consistent with Erie. In deciding Novosel, Judge Adams recognized that his task was to predict how the Pennsylvania Supreme Court would decide the problem today, and not to opt for an unthinking application of the last precedent from that court. ${ }^{171}$ Using this approach, Judge Adams found that lower Pennsylvania courts had interpreted Geary generously ${ }^{\mathbf{1 7 2}}$ and acknowledged the aggressive Yaindl balancing test to be current

${ }^{187}$ See 721 F.2d at 894,903 . Whether the Novosel court was correct in anticipating an action based on implied contract is an interesting question. Richardson v. Charles Cole Memorial Hosp., 466 A.2d 1084 (Pa. Super. 1983), decided almost simultaneously, refused to recognize such an action. More recently, however, Banas $v$. Matthews Int'l Corp., No. 1205 (Pa. Super. June 15, 1984), upheld such a claim.

${ }_{188}$ See 721 F.2d at 896.

169 See id. at 898.

$170 \mathrm{Id}$. at 900 .

171 Id. at 896-97 (citing Becker v. Interstate Properties, 569 F.2d 1203, 1206 (3d Cir. 1977), cert. denied, 436 U.S. 906 (1978), for the proposition that federal courts must take note of emerging trends when they find state law).

${ }^{172}$ See id. at 898. 
state law. ${ }^{173}$ Although Novosel was carefully constructed to avoid overruling Bonham and Bruffett, ${ }^{174}$ its interpretation of the employment at will doctrine in Pennsylvania is thoroughly contrary to those cases. Unfortunately, Novosel, a product of a faithful application of the Erie rule, has not been consistently followed. Indeed, it has been undercut by the very judge who wrote it.

In Wolk v. Saks Fifth Avenue, Inc. ${ }^{175}$ Judith Wolk alleged that she was discharged because she rebuffed her supervisor's sexual advances. Discharge for such reasons violated the sex discrimination policies of the PHRA. Affirming dismissal, Judge Adams held that the possible existence of a remedy under the PHRA precluded the recognition of a wrongful discharge action in Pennsylvania, not because the PHRA was exclusive, but because the absence of an alternative remedy was a prerequisite to recognizing a wrongful discharge action under state law. ${ }^{178}$

Wolk also claimed a violation of the terms of an implied contract under Novosel. Judge Adams distinguished and undercut his precedent by declaring that Novosel required only a careful examination of the facts. Where full discovery had already been conducted, dismissal was appropriate. ${ }^{177}$

The Wolk opinion emphasized the constraints on a federal court rather than the merits of the claim. Despite strong sympathy for the plaintiff, the court concluded that

there is no indication that the Pennsylvania courts have as yet fashioned or indicated their intention to fashion a uniform just cause requirement for all discharges. Absent such a declaration on the part of the state courts, a federal tribunal sitting in diversity is not empowered to take this step for the

173 See id. at 901.

174 Novosel noted that no alternative remedy was available, thereby satisfying the Bruffett rule. See Novosel, 721 F.2d at 898-99.

178728 F.2d 221 (3d Cir. 1984). The Wolk opinion began by stressing the "gradual emergence" of change in the common law. Id. at 222. Novosel, said the court,

must be understood against the backdrop of the limited role of a federal court sitting in diversity jurisdiction. While a federal court must be sensitive to the doctrinal trends of the jurisdiction whose law it applies, it is beyond the authority of a federal court in such circumstances to create entirely new causes of action.

Id. at 223 (citing Becker v. Interstate Properties, 569 F.2d 1203, 1206 (3d Cir. 1977), cert. denied, 436 U.S. 906 (1978), the same case cited to justify Novosel's progressive approach; see supra note 171).

176 See id. at 224.

172 See id. at 224-25. 
state courts. ${ }^{178}$

This assessment of Pennsylvania law is inappropriate. As the Novosel court recognized, Pennsylvania courts have fashioned a wrongful discharge remedy broad enough to compensate Judith Wolk, whose dismissal violated public policy as expressed in the PHRA. Wolk would thus have suffered a compensable injury even if Pennsylvania courts had never indicated their intention to fashion a uniform just cause requirement. The Yaindl balancing test, in any case, is tantamount to a just cause requirement. Although it spoke of deference to state law, the Wolk court in fact was unduly deferential to federal precedent.

Judge Adams claimed that he was bound by Bruffett, noting but not justifying the fact that Bruffett was at odds with state law. ${ }^{\mathbf{1 7 9}}$ In a footnote, he referred to the binding force of prior panels' decisions under Third Circuit Internal Operating Procedure. ${ }^{180}$ In the absence of an announcement of change by the state's highest court, Judge Adams believed that he could not depart from the holdings of earlier federal cases.

Such a refusal to examine "all available data"181 would have created a rift between state and federal interpretations of the employment at will doctrine even if federal courts had simply reiterated the doctrine in its original form every time the issue arose. Federal courts have made some concessions, however, to modern trends. Out of the tension between the need for reform and the practice of following the exact holding of the most recent precedent from the state's highest court has come a requirement unknown in state law, the lack of an alternative remedy. ${ }^{182}$

\section{The Gurrent Discrepancy Between State and Federal Courts and the Demerits of the "No Alternative Remedy" TEST}

After Wolk and Novosel, federal courts no longer deny the existence of a wrongful discharge action, ${ }^{183}$ even when they find it inappli-

${ }^{178} I d$. at 225.

179 In fact, Judge Adams highlighted this departure from state law by referring to the dissent in Bruffett. See Wolk, 728 F.2d at 224.

180 See id. at 224 n. 3 ; see also supra note 6.

181 West v. American Tel. \& Tel. Co., 311 U.S. 223, 237 (1940).

182 Indeed, at least one Pennsylvania court has recognized a cause of action for wrongful discharge notwithstanding the existence of a statutory remedy. See supra note 163 (discussing Reuther). The "no alternative remedy" requirement was therefore inconsistent with state law from the first.

${ }_{183}$ See, e.g., Hansrote v. American Indus. Technologies, Inc., No. 81-218 (W.D. Pa. June 7, 1984) (declining to overturn jury verdict for discharge against public policy 
cable to the facts or rely on earlier federal precedent to interpret it narrowly. ${ }^{184}$ But the "no alternative remedy" requirement remains a central difference between state and federal doctrine. This discrepancy can now be altered only by a decision of the Pennsylvania Supreme Court or by a Third Circuit decision en banc. An overly rigid application of Erie has meanwhile produced a persistent strain of federal common law that results in differences in outcome and subjects citizens to inequitable administration of the laws. Given the expansive range of employment abuses condemned by the PHRA, ${ }^{185}$ few wrongful discharge actions seem likely to survive in federal court.

The discrepancy has also produced a strong forum shopping incentive. Wrongful discharge defendants are typically large national corporations that are amenable to diversity jurisdiction. Whenever possible, these defendants will remove to a federal forum, because the substantive law there is friendlier to employers. It is not surprising, therefore, that federal courts have decided so many more wrongful discharge cases than state courts have. This adds a further distortion by decreasing the opportunities for state courts to clarify and develop the law. The simple command of Erie to let the common law evolve in the state courts becomes unrealistic when the overwhelming majority of cases are decided in federal forums.

Even if we leave these Erie concerns to one side, the premises of the "no alternative remedy" test seem questionable. Two rationales have been offered in defense of the test: that the creation of a common law remedy would enable plaintiffs to "circumvent the carefully drafted legislative procedures" of the PHRA, ${ }^{186}$ and that there is no need to permit a common law action when another remedy already exists. ${ }^{187}$

The first of these rationales has some initial appeal. One can readily imagine carefully drafted remedies being circumvented by coarser common law judgments. The PHRA, however, manifests no legislative intent to preclude common law remedies consistent with its policies. ${ }^{188}$

and contrary to terms of implied contract); Karr v. Township of Lower Merion, $582 \mathrm{~F}$. Supp. 410 (E.D. Pa. 1983) (denying motion to dismiss claim of wrongful discharge).

184 See, e.g., Kamens v. Summit Stainless, Inc., No. 83-3644 (E.D. Pa. Mar. 29, 1984); Buckmon v. Wilmington Dry Goods Store, No. 82-1167 (E.D. Pa. Feb. 6, 1984); Adams v. The Budd Co., 583 F. Supp. 711 (E.D. Pa. 1984). All refuse wrongful discharge actions as a matter of law, treating the public policy exception as very narrow and citing federal precedent.

${ }_{185}$ See Pa. STAT. ANN. tit. 43, § 952(b) (Purdon Supp. 1984-1985), quoted supra note 147.

186 Bruffett v. Warner Communications, Inc., 692 F.2d 910, 919 (3d Cir. 1982).

187 See id. at 920.

188 See Greenbaum, Toward a Common Law of Employment Discrimination, 58 TEMpLE L.Q. (forthcoming March 1985). Greenbaum argues that the provisions of the employment discrimination laws are not so integrally related to statutory remedies as to 
The PHRA is exclusive only when invoked ${ }^{189}$ - leaving plaintiffs the alternative of common law relief.

Even when invoked, moreover, the PHRA ultimately depends on judicial oversight. The PHRA prescribes no detailed system of remedies but rather authorizes a broad remedial scheme, including "such affirmative action . . . as, in the judgment of the Commission, will effectuate the purposes of this act."190 The legislature limited such broad discretion only by requiring that enforcement orders be secured from Pennsylvania courts. ${ }^{191}$ And if the Commission has not taken prompt action, the plaintiff is expressly permitted to turn to the courts for relief. ${ }^{192}$ The PHRA, in short, is more easily read as a supplement to common law remedies, dependent on judicial cooperation, than as a legislative substitute. $^{193}$

The superficiality of the argument that statutory remedies must be read as supplanting common law actions, is revealed by the ease with which it can be-and has been-inverted. Courts frequently conclude from the absence of explicit statutory remedies that the legislature intended not to afford a cause of action for wrongful discharge. ${ }^{194}$ If exceptions to the employment at will doctrine must rest on statutorily recognized public policy, and if statutes carrying a remedy and those

preclude common law relief and that courts are obligated to supplement statutory policies with common law remedies so long as the legislature has not clearly manifested a contrary intent.

180 See supra notes $160-61$ and accompanying text.

190 Pa. Stat. ANN. tit. 43, § 959(f) (Purdon Supp. 1984-1985).

191 See id. \& 960 (Purdon Supp. 1984-1985).

192 See id. § 962(b) (Purdon Supp. 1984-1985).

193 The PHRA's legislative history is skimpy. Nothing suggests an explicit attempt to substitute legislative remedies for judicial ones. What language there is suggests that the PHRA was intended to set certain minimum safeguards that could be enhanced by local communities or the courts. See Pennsylvania Legislative Journal-Senate 300 (Feb. 1, 1961) (remarks of Senator Weiner).

194 See, e.g., Green v. Amerada-Hess Corp., 612 F.2d 212, 214 (5th Cir. 1980) ("While the harshness of the terminable at will rule is subject to exception in light of express legislative action, the absence of explicit statutory provision of a civil remedy in the Mississippi workmen's compensation statute argues against recognizing a cause of action for retaliatory discharge."); Loucks v. Star Gity Glass Co., 551 F.2d 745, 748 (7th Gir. 1977) ("We think it rather unlikely that a retaliatory discharge prohibition would have been omitted from this comprehensive and integrated legislation if it had been intended."); McKinney v. National Dairy Council, 491 F. Supp. 1108, 1120 (D. Mass. 1980); Christy v. Petrus, 365 Mo. 1187, 1192, 295 S.W.2d 122, 126 (1956) ("[W]e feel constrained to assume that had the legislature desired to provide for [a cause of action], such a provision would have been incorporated [in the worker's compensation statute]."); Dockery v. Lampart Table Co., 36 N.C. App. 293, 297, 244 S.E.2d 272, 275 ("If the General Assembly of North Garolina had intended a cause of action be created, surely, in a workmen's compensation statute as comprehensive as ours, it would have specifically addressed the problem."), cert. denied, 295 N.C. 465, 246 S.E.2d 215 (1978). 
making no explicit provision for one are both excluded, then little scope would seem to remain for the exception. One can escape this paradoxical conclusion only by recognizing that the presence or absence of an explicit statutory remedy does not in itself support an inference that the legislature either did or did not intend that an alternative, common law remedy be available. ${ }^{195}$

The second rationale for the "no alternative remedy" requirement-that the existence of one remedy obviates the need for another-also has some intuitive validity. But the presence of an alternative remedy makes a common law action unnecessary only where the remedy provides comparable relief. Pennsylvania courts have consistently held that the Human Relations Commission has no authority to award compensatory damages or damages for mental anguish, inconvenience, humiliation, or disruption of normal family life. ${ }^{186}$ These injuries are integral to the loss of employment. They are likely components of any jury award for wrongful discharge, ${ }^{197}$ and there is no alternative remedy for them.

\section{Conclúsion}

In areas of rapidly changing law, federal courts sitting in diversity jurisdiction inevitably play a formative role. Interpreting change narrowly does not diminish federal influence; on the contrary, it may lead to distortions of state law and cause forum shopping effects as severe as those forbidden by Erie. While a federal court must not substitute its preferences for established state law, federal courts must be as willing as intermediate state courts to extend the law.

The current status of the employment at will doctrine in Pennsylvania is an example of distortion arising from aversion to change. Most federal cases decided in Pennsylvania have adopted a narrow approach unsupported by Pennsylvania law as the state courts have expressed it. Federal courts continue to apply conservative federal precedent, un-

103 See generally Gamm \& Eisberg, The Implied Rights Doctrine, 41 UMKC L. REv. 292 (1972); Note, Implying Remedies from Federal Regulatory Statutes, 77 HARV. L. REV. 285, 289-91 (1963).

${ }_{198}$ See, e.g., Lee v. Walnut Garden Apartments, Inc., 479 Pa. 142, 387 A.2d 875 (1978); Pennsylvania Human Relations Comm'n v. Zamantakis, $478 \mathrm{~Pa}$. 454, 387 A.2d 70 (1978) (per curiam). The court in Zamantakis reasoned that the Pennsylvania Human Relations Commission should not be empowered to award such damages because it lacked all the "formal trappings, evidentiary protections, and strict procedures. of a court of law"-language that highlights the limits of the PHRA as an alternative remedy. Id. at 458,387 A.2d at 72 (footnote omitted).

${ }_{197}$ Cf. Banas v. Matthews Int'l Corp., No. 1205 (Pa. Super. June 15, 1984) (vacating and remanding jury award of $\$ 40,000$ for defamation and punitive damages in wrongful discharge action). 
deterred by later state interpretations. They have created a requirement that no alternative be available to a common law remedy, thereby limiting the reach of change in state law, and the requirement persists despite increasingly liberal state decisions. Although Novosel v. Nationwide Insurance Co. ${ }^{188}$ has finally established a federal precedent more indicative of present state law, it has not overthrown the "no alternative remedy" requirement.

The Erie doctrine need not limit federal courts to mimicking the last state supreme court precedent, nor does it forbid federal courts to initiate change. While federal courts must engage in an honest investigation of current state law, a degree of critical analysis and independence of judgment is essential to competent adjudication. With it must come a willingness to change when necessary. 